\title{
Synthesis and Characterization of Cobalt(III) and Copper(II) Complexes of 2-((E)-(6-Fluorobenzo[d]thiazol-2-ylimino) methyl)-4-chlorophenol: DNA Binding and Nuclease Studies-SOD and Antimicrobial Activities
}

\author{
K. Savithri $\mathbb{D}^{1}{ }^{1}$ B. C. Vasantha Kumar, ${ }^{1}$ H. K. Vivek, ${ }^{2}$ and H. D. Revanasiddappa $\mathbb{D}^{1}$ \\ ${ }^{1}$ Department of Studies in Chemistry, University of Mysore, Mysuru, Karnataka 570 006, India \\ ${ }^{2}$ Sri Ram Chem, R\&D Center, JCK Industrial Park, Belagola Industrial Area, Mysuru 571 606, India
}

Correspondence should be addressed to H. D. Revanasiddappa; hdrevanasiddappa@yahoo.com

Received 21 August 2017; Accepted 16 January 2018; Published 1 March 2018

Academic Editor: Hakan Arslan

Copyright (C) 2018 K. Savithri et al. This is an open access article distributed under the Creative Commons Attribution License, which permits unrestricted use, distribution, and reproduction in any medium, provided the original work is properly cited.

\begin{abstract}
A bidentate $(\mathrm{N}$ - and $\mathrm{O}-)$ imine-based ligand $\left(L_{1}\right)$ and its metal complexes of types $\left[\mathrm{Cu}^{\mathrm{II}}\left(\mathrm{L}_{1}\right)_{2}\right]\left(C_{1}\right),\left[\mathrm{Cu}^{\mathrm{II}}\left(\mathrm{L}_{1}\right)\left(\mathrm{Phen}^{\mathrm{N}}\right)\right]\left(\mathrm{C}_{2}\right)$, $\left[\mathrm{Co}^{\mathrm{III}}\left(\mathrm{L}_{1}\right)_{2}\right]\left(\mathrm{C}_{3}\right)$, and [Co $\left.{ }^{\mathrm{III}}\left(\mathrm{L}_{1}\right)(\mathrm{Phen})\right]\left(\mathrm{C}_{4}\right)\left(\mathrm{L}_{1}=2-((\mathrm{E})-(6\right.$-fluorobenzo[d]thiazol-2-ylimino)methyl)-4-chlorophenol and phen $=1,10$-phenanthroline) were synthesized as potential chemotherapeutic drug candidates. The prepared complexes were structurally characterized by spectral techniques (NMR, FT-IR, LC-MS, EPR, and electronic absorption), thermogravimetric analysis (TGA/DTA), magnetic moment, and CHNO elemental analysis. Spectroscopic studies suggested the distorted octahedral structure for all complexes. In vitro bioassay studies include binding and nuclease activities of the ligand and its complexes with target calf thymus- (CT-) DNA were carried out by employing UV-Vis, fluorescence spectroscopy, viscosity, and gel electrophoresis techniques. The extent of binding propensity was determined quantitatively by $K_{b}$ and $K_{\mathrm{sv}}$ values which revealed a higher binding affinity for $\mathrm{C}_{2}$ and $\mathrm{C}_{4}$ as compared to $\mathrm{C}_{1}$ and $\mathrm{C}_{3}$. In addition, the scavenging superoxide anion free radical $\left(\mathrm{O}^{\circ-2}\right)$ activity of metal complexes was determined by nitroblue tetrazolium (NBT) light reduction assay. Molecular docking studies with DNA and SOD enzyme were also carried out on these compounds. The antimicrobial study has shown that all the compounds are potential antibacterial agents against Gram-negative bacterial strains and better antifungal agents with respect to standard drugs used.
\end{abstract}

\section{Introduction}

Imine-based ligands coordinated to transition metal ions have several advantages, are also very popular now, and are being used at the forefront of the development of DNA molecular probes (DNA-binding metal complexes) and therapeutic agents $[1,2]$. Transition metal complexes that are suitable for binding and cleaving nucleic acids are of significant interest due to their various applications in nucleic acid chemistry, like foot-printing studies and sequence-specific binding agents and also as a putative anticancer drug.

DNA executes an imperative constituent for many biochemical progressions that rise in the cellular system as in various regulatory processes/gene expressions. These processes can be modified by the interaction of chemical compounds with specific regions of DNA. Some of the d-block metal complexes activate endonucleolytic cleavage reaction in DNA photolytically or with the aid of external agents [3]. DNA is an attractive motif for the design of novel chemotherapeutics of cancer as the process involves DNA replication during the $S$ phase of cell cycle [4]. The covalent and noncovalent interactions of transition metal complexes with DNA lead to biological activity $[5,6]$. The DNA cleavage is an important enzymatic reaction involved in several biological processes as well as in biotechnological manipulation of genetic material. Artificial DNA cleaving agents could find applications in several fields, in nucleic acids structural studies, natural process as biotechnological manipulation of genetic material, or drug development [7]. Medicinal inorganic chemistry covers broad applications of 
metals in pharmaceuticals [8]. Chemically, Lewis acidic metal centers are well opting to influence fundamental cellular processes due to their affinity for basic $\mathrm{N}$ - and $\mathrm{O}$ - donor ligands, large aromatic manners capable of $\pi$-interactions with nucleic acid building blocks.

A bicyclic heteronuclear compound comprises benzothiazole-a unique synthon in synthetic therapeutic chemistry [9]. 2-Amino benzothiazole derivatives have received considerable attention owing to their unique structures and exquisite pharmacophores observed in many diagnostic and therapeutic agents. A literature review has illustrated that the substitution at 4,5 , and 6 th positions of 2 -aminobenzothiazole improves biological activities. Moreover, imine bases derived from 2-aminobenzothiazole are of great importance due to their wide applications as antimicrobial, anti-inflammatory, antidegenerative, and antiHIV agents [10-12]. Fluorobenzothiazole derivatives possess exquisite potency and selectivity in cytotoxicity with a broad spectrum of action than their parent nonfluorinated counterparts and have been therefore comprehensively explored for chemotherapeutic applications in drug design $[13,14]$.

Recently, metal complexes have shown biological activity in many mammalian cell systems in vitro and in vivo [15]. Metal complexes of imine bases derived from substituted aldehydes and heterocyclic compounds containing nitrogen, sulfur, and/or oxygen as ligand atoms are of interest as simple structural models of more complicated biological systems [16]. Hence, much attention has been given on the design of metal-based complexes. Copper is an essential endogenously biocompatible metal ion found in the living system which may be less toxic than the other nonessential metal ions. $\mathrm{Cu}$ (II) complexes are preferred candidates for various pharmacostudies due to the presence of its biorelevant ligands which can bind and cleave DNA [17]. The biological behavior of $\mathrm{Cu}$ (II) complexes has been subjected to intense investigation for DNA binding and cleavage activities [18] for novel chemotherapeutics and highly sensitive diagnostic agents [19]. Structural features and donor atoms of the complex may influence significant factors such as the lipophilic/hydrophilic nature of the compound, the favoured oxidation state of the copper center, and the observed biological reactivity of the complexes [20]. Cobalt involves itself in the regulation of DNA synthesis indirectly and in cobalt-dependent proteins which make it an essential biological element [21]. Cobalt(III) complexes have been widely investigated in coordination chemistry and biochemistry [22] owing to their therapeutic activities [23]. Copper and cobalt are bioessential metals in all living systems which show antifungal and antibacterial properties against several pathogenic fungi and bacteria depending on the reaction with the central DNA system [24]. The binding of fluorescent polycyclic molecules to DNA can be conveniently investigated by a variety of techniques, including absorption and fluorescence spectroscopic methods because their absorption and emission properties significantly change on complex formation [25].

Superoxide dismutase (SOD) is found in many organisms, and there still exist some shortcomings in a wide range of clinical applications of SOD [26]. Hence, special attention is paid to the artificial mimics of SOD. Developing highly efficient and stable SOD mimics is one of the crucial projects in biochemistry [27]. Copper complexes of salicylic acid are potent SOD mimetic as transition metal ion complexes have generally been used as antioxidants to eliminate noxious reactive oxygen species. Among the reported mimics, the highest SOD-like activity is only $20 \%$ of the bovine erythrocyte $\mathrm{Cu}$, $\mathrm{Zn}$-SOD [28]. Along with copper, some of the metals such as iron [29], manganese [29, 30], ruthenium [31], and cobalt [32] show a marked SOD activity and seem to retain it in living cells which has been reported [33]. Molecular dynamics in computational chemistry track precise dynamics in atomic detail. They allow for the simulation to be extended to larger molecular systems, like proteins and nucleic acids as their approach accurately and efficiently explores conformational space with improved sampling and converges to the correct canonical probability distribution [34].

In continuation of our previous research work [35] on the detailed study of $\mathrm{L}_{1}$, the present research paper describes the synthesis of imine-based complexes of essential transition metals involving $\mathrm{Co}$ (III) and $\mathrm{Cu}$ (II) and mixed ligand complexes in presence of 1,10-phenanthroline. The prepared complexes were subjected to spectroscopic structural elucidation. The interaction of complexes with DNA has also been investigated using electronic absorption, fluorescence spectroscopy, viscosity measurement, and gel electrophoresis. The SOD mimic activity was determined using a nonenzymatic NBT system. Molecular docking studies were to unravel the mode of binding of the compounds with DNA and SOD. With investigation of the antimicrobial (against pathogenic strains of bacteria and fungi), a minimum concentration of the compounds sufficient to inhibit the microbial growth (MIC) was obtained with a focus on potential new and unique and versatile scaffolds for pharmaceutical efficacy profile.

\section{Experimental Section}

2.1. Materials. $\mathrm{CuCl}_{2} \cdot 2 \mathrm{H}_{2} \mathrm{O}, \mathrm{CoCl}_{2} \cdot 6 \mathrm{H}_{2} \mathrm{O}, \mathrm{DMSO}$, superoxide dismutase (SOD), methyl green, ascorbic acid, sodium azide $\left(\mathrm{NaN}_{3}\right)$, Tris(hydroxymethyl)aminomethane, disodium salt of calf thymus DNA (highly polymerized, stored at $4^{\circ} \mathrm{C}$ ), 4,6-diamino-phenylindole (DAPI), $\mathrm{H}_{2} \mathrm{O}_{2}$ (Merck), NBT, pUC18 supercoiled plasmid DNA (Genei), and ethidium bromide (EB) were purchased from Sigma Corp. and they were used as supplied.

2.2. Methods and Instrumentation. The melting point determination in an open capillary tube using a precision digi melting point apparatus and was uncorrected. Mass spectra of synthesized compounds were recorded using a $2010 \mathrm{EV}$ LC-MS Shimadzu spectrometer. Microanalysis (C, H, N, O, and $\mathrm{M}$ ) was performed on a Perkin-Elmer elemental analyzer. Magnetic susceptibility measurements were performed by the Gouy technique in the solid state at room temperature and $\mathrm{Hg}\left[\mathrm{Co}(\mathrm{NCS})_{4}\right]$ is the standard used. Electronic spectra were recorded $(200-800 \mathrm{~nm})$ in DMSO using a UV-Vis spectrophotometer (DU 730 "Life Science" M/S, Beckman Coulter, USA). IR spectra were recorded on a PerkinElmer 783 spectrophotometer via attenuated total reflection (FT-ATR) in the range of $4000-400 \mathrm{~cm}^{-1}$. TGA analysis 


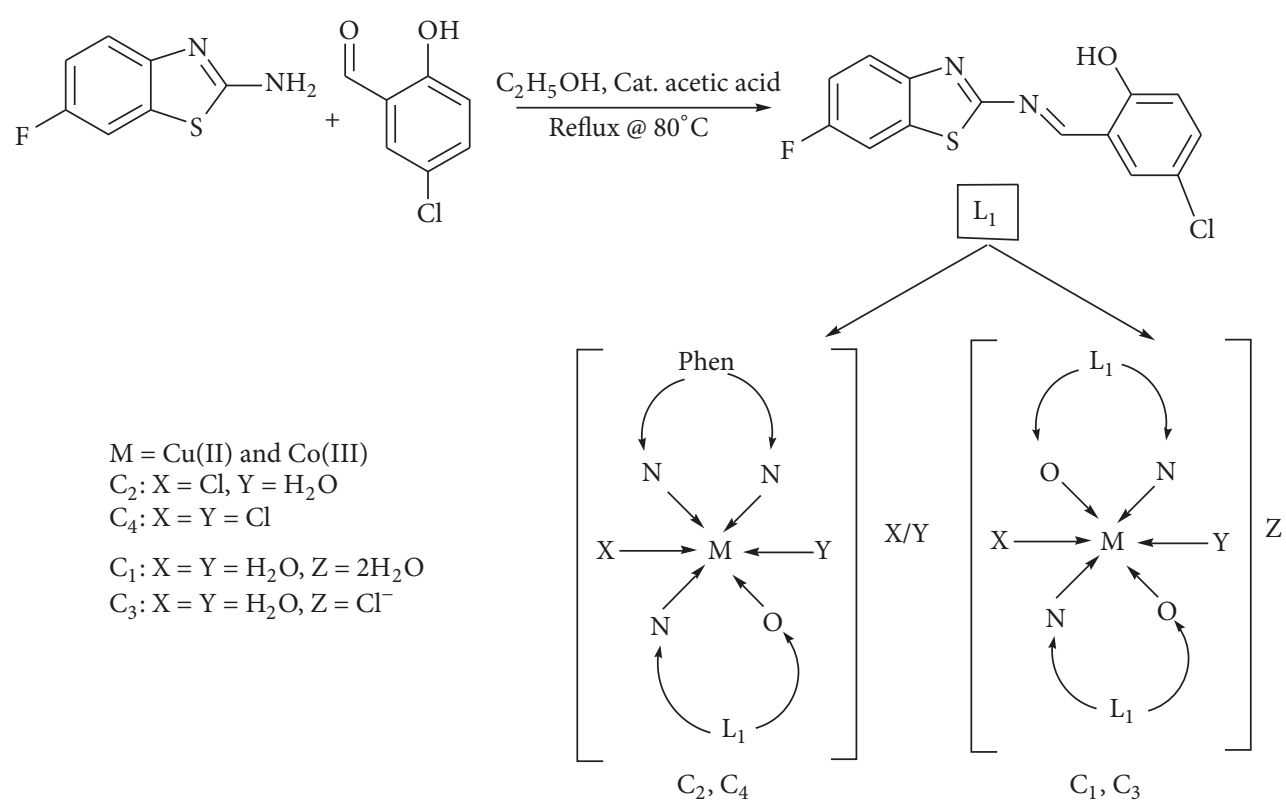

FIGURE 1: General scheme for the synthesis of $\mathrm{L}_{1}$ and its metal complexes.

was performed on Shimadzu AT-50 thermal analyzer from 25 to $700^{\circ} \mathrm{C}$ with a heating rate at $10^{\circ} \mathrm{C} / \mathrm{min}$ under $\mathrm{N}_{2}$ atmosphere. Electron paramagnetic resonance (EPR) spectra were recorded using a JEOL JES-TE100 EPR spectrometer in DMSO solution at LNT in the solid state on X-band at a frequency of $9.13 \mathrm{GHz}$ under the magnetic field of $300 \mathrm{mT}$. Fluorescence measurements were performed on RF-5301P spectrofluorophotometer (Shimadzu) equipped with a 150-W Xenon lamp, using a quartz cell path length of $1 \mathrm{~cm}$ at a slit width of $5.0 \mathrm{~nm}$.

2.2.1. Synthesis of Metal Complexes $\left(C_{1}\right.$ and $\left.C_{3}\right)$. A synthetic scheme (Figure 1) of metal complexes and mixed ligand complexes is described as follows.

The ligand, $\mathrm{L}_{1}(2 \mathrm{mmol})$, was dissolved in ethanol by heating and intensive stirring. To the warm suspension, a warm ethanol solution of $\mathrm{CuCl}_{2} \cdot 2 \mathrm{H}_{2} \mathrm{O}$ and/or $\mathrm{CoCl}_{2} \cdot 6 \mathrm{H}_{2} \mathrm{O}$ ( $1 \mathrm{mmol}$ ) was added dropwise. The resulting mixture was kept under reflux over a water bath for $4 \mathrm{~h}$ at $80^{\circ} \mathrm{C}$. The solvent was evaporated in vacuo, and the obtained solid was directly used for further processing.

2.2.2. Synthesis of Mixed Ligand Complexes $\left(C_{2}\right.$ and $\left.C_{4}\right)$ with 1,10-Phenanthroline. An ethanolic solution of 1,10phenanthroline ( $1 \mathrm{mmol}$ ) was added to hot ethanolic solution of $\mathrm{CuCl}_{2} \cdot 2 \mathrm{H}_{2} \mathrm{O} / \mathrm{CoCl}_{2} \cdot 6 \mathrm{H}_{2} \mathrm{O}(1 \mathrm{mmol})$ with constant stirring, followed by dropwise addition of ethanolic $\mathrm{L}_{1}(1 \mathrm{mmol})$. The reaction mixture was then refluxed for $4.5 \mathrm{~h}$ at $60^{\circ} \mathrm{C}$. Later, the obtained precipitate was filtered and washed with cold ethanol twice. The solid product was dried under desiccator and weighed.

$\mathrm{C}_{1}$ : $\left[\mathrm{Cu}\left(\mathrm{L}_{1}\right)_{2}\left(\mathrm{H}_{2} \mathrm{O}\right)_{2}\right]\left(\mathrm{H}_{2} \mathrm{O}\right)_{2}$. Yield $=70 \%$, brown color, Anal. (\%) for $\mathrm{C}_{28} \mathrm{H}_{22} \mathrm{Cl}_{2} \mathrm{CuF}_{2} \mathrm{~N}_{4} \mathrm{O}_{6} \mathrm{~S}_{2}$ : Found (Calc.): $\mathrm{C} 45.03$ (45.02), H 2.95 (2.97), Cu 8.52 (8.51), N 7.48 (7.50), O
12.82 (12.85); $m p=>300^{\circ}$ C. $m / z: 747.07,749.21,750.14 ; I R$ $\left(v_{\max } / \mathrm{cm}^{-1}\right):(\mathrm{HC}=\mathrm{N})$ azomethine $1639 ; \mathrm{M}-\mathrm{O} 568 ; \mathrm{M}-\mathrm{N} 445$; $\mathrm{H}_{2} \mathrm{O} 3392,862$.

$\mathrm{C}_{2}:\left[\mathrm{Cu}\left(\mathrm{L}_{1}\right)(\right.$ phen $\left.)\left(\mathrm{H}_{2} \mathrm{O}\right)(\mathrm{Cl})\right]$. Yield $=68 \%$, inchworm green color, Anal. (\%) $\mathrm{C}_{27} \mathrm{H}_{20} \mathrm{Cl}_{2} \mathrm{CuFN}_{4} \mathrm{O}_{2} \mathrm{~S}$ : Found (Calc.) C 54.81 (52.47), H 3.27 (3.26), Cu 10.26 (10.28), N 9.06 (9.07), O 75.14 (5.18); $m p=286-288^{\circ}$ C. $m / z: 617.98,620.32 ; I R\left(v_{\max } / \mathrm{cm}^{-1}\right)$; $(\mathrm{HC}=\mathrm{N})$ azomethine 1638; M-O 576; M-N 442; M-Cl 371; $\mathrm{H}_{2} \mathrm{O} 3382,851$.

$\mathrm{C}_{3}$ : $\left[\mathrm{Co}\left(\mathrm{L}_{1}\right)_{2}\left(\mathrm{H}_{2} \mathrm{O}\right)_{2}\right] \mathrm{Cl}$. Yield $=72 \%$, brown color, Anal. (\%) for $\mathrm{C}_{28} \mathrm{H}_{18} \mathrm{Cl}_{3} \mathrm{CoF}_{2} \mathrm{~N}_{4} \mathrm{O}_{4} \mathrm{~S}_{2}{ }^{-}$; Found (Calc.) $\mathrm{C} 45.33$ (45.31), H 2.45 (2.44), Co 7.94 (7.90), N 7.55 (7.54), O 8.63 (8.61); mp $=294-296^{\circ} \mathrm{C} . \mathrm{m} / z: 741.88,744.32,745.26 ; \operatorname{IR}\left(v_{\max } / \mathrm{cm}^{-1}\right)$; $(\mathrm{HC}=\mathrm{N})$ azomethine 1640; M-O 542; M-N 463; M-Cl 362, $\mathrm{H}_{2} \mathrm{O} 3387,856$.

$C_{4}:\left[\mathrm{Co}\left(L_{1}\right)(\right.$ phen $\left.)(C l)_{2}\right]$. Yield $=63 \%$, bottle green color, Anal. (\%) for $\mathrm{C}_{26} \mathrm{H}_{15} \mathrm{Cl}_{3} \mathrm{CoFN}_{4} \mathrm{OS}$ : Found (Calc.) C 50.70 (50.71), H 2.45 (2.46), Co 9.54 (9.57), N 9.08 (9.10), O 2.59 (2.60); $m p \geq 300^{\circ} \mathrm{C} . \mathrm{m} / z: 615.77,618.36$; IR $\left(v_{\max } / \mathrm{cm}^{-1}\right)$; $(\mathrm{HC}=\mathrm{N})$ azomethine 1633; M-O 576; M-N 468; M-Cl 372.

\subsection{Bioassay Studies}

\subsubsection{DNA-Binding Experiments}

Electronic Absorption Spectral Titration. The stock solution of CT-DNA was prepared in $5 \mathrm{mM}$ Tris- $\mathrm{HCl} / 50 \mathrm{mM} \mathrm{NaCl}$ buffer at $\mathrm{pH} 7$, which gave $A_{260} / A_{280 \mathrm{~nm}}$ of ca. 1.8-1.9, indicating that the DNA was sufficiently devoid of protein [36], and the concentration of DNA was determined from its absorption intensity at $260 \mathrm{~nm}\left(\varepsilon_{260}=6600 \mathrm{M}^{-1} \mathrm{~cm}^{-1}\right)$ [37]. All the stock solutions were stored at $4^{\circ} \mathrm{C}$ and used 
within four days. The intrinsic binding constant $\left(K_{b}\right)$ values of the complexes to CT-DNA were obtained by monitoring the change in the absorption intensity of the spectral bands with increasing concentration of DNA. After equilibrium had been reached, the spectra were recorded at 200-500 nm against an analogous solution of DNA as a reference. UV spectral data were fitted into Wolfe-Shimer equation (1) [38] to obtain the intrinsic binding association constant $\left(K_{b}\right)$ :

$$
\frac{[\mathrm{DNA}]}{\varepsilon_{a}-\varepsilon_{b}}=\frac{[\mathrm{DNA}]}{\varepsilon_{b}-\varepsilon_{f}}+\frac{1}{K_{b}\left(\varepsilon_{b}-\varepsilon_{f}\right)},
$$

where [DNA] is the concentration of DNA in base pairs, $\varepsilon_{a}$ is apparent extinction coefficient $\left(A_{\mathrm{obs}} /[\mathrm{MC}]\right), \varepsilon_{b}$ is the extinction coefficient of the metal complex in the fully bound form, and the extinction coefficient for free metal complex [MC] is $\varepsilon_{f}$. The value of $K_{b}$ was calculated as the ratio of the slope to intercept.

Fluorimetric Studies. Ethidium bromide (EB) emits intense fluorescence light in the presence of DNA at $\lambda_{\text {ex }} 600 \mathrm{~nm}$ $(546 \mathrm{~nm})$ due to strong intercalation between adjacent DNA base pairs. The fluorescence emission intensity can be quenched when the second molecule was added to the CTDNA bound EB solution. In the fluorescence quenching study, $[\mathrm{DNA}] /[\mathrm{EB}]=1.13$ is kept constant and varied with the concentration of the compounds. The fluorescence spectra of the reaction mixture were recorded between 500 and $850 \mathrm{~nm}$ at excitation wavelength $515 \mathrm{~nm}$. The fluorescence quenching efficiency is evaluated according to the classical Stern-Volmer equation (2). The binding constant $\left(K_{b}\right)$ and number of binding sites $(n)$ can be determined from emission spectra with (3).

$$
\begin{gathered}
\frac{F_{o}}{F}=1+K_{\mathrm{sv}} Q \\
\log \left(\frac{F_{o}-F}{F}\right)=\log K_{b}+n \log [Q] .
\end{gathered}
$$

The fluorescence intensities in absence and presence of the quencher (complexes) are termed $F_{o}$ and $F$ as, respectively, " $Q$ " is the concentration of the quencher and $K_{\text {sv }}$ is the SternVolmer quenching constant.

Viscosity Measurements. Viscosity experiments were carried out on an Ostwald microviscometer, immersed in a thermostat water bath maintained at a constant temperature at $26^{\circ} \mathrm{C}$. Compounds were added to DNA solution $\left(10 \mu \mathrm{molL}^{-1}\right)$ with a micropipette. The concentration of the compounds was maintained in the range of $0-10 \mu \mathrm{ML}^{-1}$. Data were graphically presented as $\left(\eta / \eta_{o}\right)^{1 / 3}$ versus the ratio of the concentration of compounds to DNA $(r)$, where $\eta$ was the viscosity of DNA in the presence of compound and $\eta_{o}$ was the viscosity of DNA alone. The relative viscosity $\eta$ was calculated using [39]

$$
\eta=\frac{\left(t-t_{o}\right)}{t_{o}}
$$

where $t_{o}$ and $t$ represent the flow time of buffer solution through the capillary and observed flow time for DNA in the absence and presence of the complex, respectively. The mean of three replicate measurements was used to evaluate the viscosity of the samples.

2.3.2. DNA Cleavage Assay. Agarose-gel electrophoresis monitored the ability of transition metal complexes to cleave plasmid DNA. The experiment was accomplished with supercoiled pUC18 $(200 \mathrm{ng}, 1 \mu \mathrm{L})$ which was treated with varying concentrations of compounds $(10-50 \mu \mathrm{M})$ in Trisboric acid-buffer with $\mathrm{NaCl}(50 \mathrm{mM}, \mathrm{pH} 7.2)$ by agarosegel electrophoresis method. The samples ( $5 \mu \mathrm{L}$ in Tris-buffer) were incubated at $37^{\circ} \mathrm{C}$ for $45 \mathrm{~min}$ in water bath; to this solution, $1 \mu \mathrm{L}$ loading buffer $(0.25 \%$ bromophenol blue and $30 \%$ glycerol) was added. This mixture was loaded in the $1 \%$ agarose gel and electrophoresis was carried out at $60 \mathrm{~V}$ for an hour. The agarose gel was prestained with $0.5 \mu \mathrm{g} / \mathrm{mL}$ ethidium bromide (EtBr) and visualized under UV light and photographed for further analysis. The cleavage properties were determined based on the ability of compounds to convert the supercoiled form (Form I) into nicked (Form II) and linear form (Form III) [23].

2.3.3. Superoxide Dismutase (SOD) Assay. The superoxide dismutase activities of the synthesized metal complexes were assessed by colorimetric-based assay with xanthine/xanthine oxidase system as the source of $\mathrm{O}_{2}{ }^{--}$due to their conducive solubility. The quantitative reduction of nitroblue tetrazolium (NBT) to monoformazan $\left(\mathrm{MF}^{+}\right)$by the $\mathrm{O}_{2}{ }^{\cdot-}$ changes the color from yellow to blue which was followed spectrophotometrically at $560 \mathrm{~nm}$. The suppression ratio was calculated using standard equation $\left[A_{\text {control }}-A_{\text {sample }} / A_{\text {control }}\right] \times 100$. In the SOD-like activity test, the metal complexes compete with NBT for oxidation of the generated superoxide ions. Plotting the results as the percentage of inhibiting NBT for comparative concentrations of complexes was determined by absorption changes. Tabulated results were derived from linear regression analysis and are given as the concentration $(\mu \mathrm{M})$ equivalent to 1 unit of native $\mathrm{Cu} \mathrm{Zn}$-SOD activity $\left(\mathrm{IC}_{50}=0.04 \mu \mathrm{M} \mathrm{dm}^{-3}\right)$ [40]. A unit SOD activity is the concentration of the complex or enzyme which causes $50 \%$ inhibition in the reduction of NBT.

2.3.4. Molecular Docking. Crystal structure of DNA dodecamer (1BNA.pdb) with the sequence of $d(C p G p C p G p A-$ pApTpTpCpGpCpG) and $\mathrm{Cu}, \mathrm{Zn}-\mathrm{SOD}$ (1CB4) was downloaded from the protein data bank (http://www.rcsb.org) and used for docking studies. Compounds were drawn using Maestro 2D sketcher and energy minimization was computed by OPLS 2005, while, for the preparation of the DNA or $\mathrm{Cu}$, $\mathrm{Zn}$-SOD, hydrogen was added to the polar atoms and the valency of the metal ions was optimized [41]. Meanwhile, the water molecules and the substrate were deleted. The DNA was minimized to some extent after hydrogen was added. Finally, a grid for DNA [with the dimension $(10 \AA \times 10 \AA \times 10 \AA)$ ] and $\mathrm{Cu}, \mathrm{Zn}$-SOD [with the dimension $(20 \AA \times 20 \AA \times 20 \AA)$ ] were prepared. The dimension of the grid was in such a manner 
that the grid covers the complete DNA. Using Extraprecision (XP) docking protocol, compounds were evaluated based on glide scoring which was docking into the receptor grid of radii as mentioned above [42].

2.3.5. Antimicrobial Activity. All the synthesized compounds were screened in vitro for their antimicrobial activity against Gram -ve bacteria as Escherichia coli (MTCC 443) and Pseudomonas aeruginosa (MTCC 2453) and Gram +ve bacterial strains as Bacillus subtilis (MTCC 121) and Staphylococcus aureus (MTCC 3160), and fungal strains are Candida albicans (ATCC 10231) and Aspergillus niger (ATCC 6275), and standard antibiotic ciprofloxacin $(25 \mathrm{mg})$ and antifungal fluconazole ( $25 \mathrm{mg}$ ) served as the positive control. The impact was tested in terms of minimum inhibitory concentration (MIC) using a serial plate dilution assay [43]. Microbial cultures were incubated at $37^{\circ} \mathrm{C}$ for a day in case of bacteria and $72 \mathrm{~h}$ for fungi, respectively. $100 \mu \mathrm{L}$ of Mueller-Hinton broth of bacteria was pipetted into each well; to this, a $10 \mu \mathrm{L}$ suspension of the test pathogens was then added. 4\% DMSO was used as a solvent for solution preparation and served as a negative control in order to monitor sample sterility and to determine any antimicrobial influence of the solvent. Inhibition zone was measured, and MIC was determined using double-fold serial dilution in liquid media containing varying concentrations of test compounds from 1 to $1000 \mu \mathrm{g} / \mathrm{mL}$. Bacterial growth was measured by the turbidity of the culture after $18 \mathrm{~h}$. Turbidity standard as McFarland Standard 0.5 solution was used. If particular concentration of compound inhibits bacterial growth, half the concentration of the compound was tested. This procedure was carried on to a concentration at which bacteria grow normally. The lowest concentration that inhibits the bacterial growth was determined as MIC value. Three replicates were maintained per test microbe. The resultant MIC values were determined as the mean of these replicate experiments.

\section{Results and Discussion}

3.1. Chemistry. A new potential $\mathrm{N}$ and O-bidentate iminebased ligand $\left(\mathrm{L}_{1}\right)$ and its $\mathrm{Co}(\mathrm{III})$ and $\mathrm{Cu}(\mathrm{II})$ complexes were prepared by usual literature protocol, and a microanalysis checked the purity for $\mathrm{C}, \mathrm{H}, \mathrm{O}$, and $\mathrm{N}$. Cobalt(III) complexes were obtained by aerobic/chemical oxidation of mixtures of $\mathrm{Co}(\mathrm{II})$ salts and the ligand $[44,45]$. Analytical data of all the complexes $\left(\mathrm{C}_{1}-\mathrm{C}_{4}\right)$ are summarized above and the results obtained are reliable with those calculated for the proposed formulae. All the compounds were stable at atmospheric conditions, nonhygroscopic, and highly soluble in organic solvents such as DMF and DMSO. The molar conductivity of the complexes in DMSO $\left(10^{-3} \mathrm{M}\right)$ at $26^{\circ} \mathrm{C}$ is commensurate with their nonelectrolytic nature $\left(13-18 \Omega^{-1} \mathrm{~cm}^{2} \mathrm{~mol}^{-1}\right)$, but the cobalt(III) complex $\left(\mathrm{C}_{3}\right)$ tends to be in an electrolytic environment with their ionic behavior at higher conductivity $\left(38 \Omega^{-1} \mathrm{~cm}^{2} \mathrm{~mol}^{-1}\right)$. However, the analytical, spectroscopic, and magnetic data do enable us to predict the possible structure of the synthesized complexes.

\subsection{Spectral Characterization}

3.2.1. Vibrational Spectroscopy. IR spectra of the complexes were studied concerning the spectrum of the free ligand to characterize the binding mode of the imine-based ligand to the metal ion in complexes. The IR spectrum (Figure S1) of free ligand exhibits a sharp band at $1662 \mathrm{~cm}^{-1}$ due to azomethine group vibration. This band is shifted to longer wavelength (lower wavenumber) in the range $1650-1634 \mathrm{~cm}^{-1}$ of the complexes and confirms the coordination of the imine nitrogen to the metal ion. $\mathrm{L}_{1}$ has the characteristic band at $1562 \mathrm{~cm}^{-1}$ for $\mathrm{C}=\mathrm{N}$, thiazole ring. Spectra of complexes exhibited a new broad band in the range " $3500-3400$ " $\mathrm{cm}^{-1}$ which may be attributed to stretching vibration $v(\mathrm{OH})$ of hydrated water, which is ensured by thermal analysis. The phenolic -OH stretching frequency at $1267 \mathrm{~cm}^{-1}$ found in the spectrum of the Schiff base was absent in the spectra of metal complexes and might be due to the coordination of the phenol oxygen atom involved in complexation as C-O-M at $\sim 1224 \mathrm{~cm}^{-1}$ [46]. In the spectra of all the metal complexes, a very broadband at $3500 \mathrm{~cm}^{-1}$ is observed signifying the presence of coordinated/lattice held water. The bands due to $\mathrm{M}-\mathrm{O}$ and $\mathrm{M}-\mathrm{N}$ (coordination of azomethine nitrogen vibrational modes) appeared in the range of 565-490 and $470-435 \mathrm{~cm}^{-1}$, respectively [47].

3.2.2. Electronic Spectra and Magnetic Moment. The electronic spectral measurements used to assign the possible geometry of the complexes are based on d-d transition peaks. Electronic spectra of the ligand and its metal complexes were measured in DMSO, and the numerical data are listed in Table S1. In Figure S2, a very strong band is below $400 \mathrm{~nm}$ for Schiff base $(303 \mathrm{~nm})$ and at $344 \mathrm{~nm}$ for complexes, due to ligand-centered $\pi \rightarrow \pi^{*} / n \rightarrow \pi^{*}$ (most probably from phenolate oxygen donor atom) transitions (LLCT). The absorption band observed at around $330-350 \mathrm{~nm}$ is attributed to ligand-centered charge transfer including $n \rightarrow \pi^{*}$ transitions of phenanthroline. Besides a moderate broadband found at $385-410 \mathrm{~nm}$ with absorption maxima $\left(\lambda_{\max }\right)$ at $406 \mathrm{~nm}\left(\mathrm{C}_{1}\right), 400-410 \mathrm{~nm}\left(\mathrm{C}_{2}\right), 385 \mathrm{~nm}\left(\mathrm{C}_{3}\right)$, and $405 \mathrm{~nm}$ $\left(\mathrm{C}_{4}\right)$ were attributed to the metal ligand charge transfer (MLCT) transitions in complexes. The spectra further display a broadband in the region $460-580 \mathrm{~nm}$ with an absorption maximum at $520 \mathrm{~nm}$ which is due to several metal-centered $\mathrm{d}$ - $\mathrm{d}$ transitions which may be assigned to $\mathrm{d}$ - $\mathrm{d}$ transitions of a distorted octahedral copper(II) chromophore and it may be assigned to ${ }^{2} \mathrm{Eg} \rightarrow{ }^{2} \mathrm{~T}_{2 \mathrm{~g}}$ transition [48]. Lower energy band at $\lambda_{\max } 502-550 \mathrm{~nm}$ is attributed to ${ }^{1} \mathrm{~A}_{1 \mathrm{~g}} \rightarrow{ }^{1} \mathrm{~T}_{2 \mathrm{~g}}\left(\nu_{1}\right)$ ligand field transitions in an octahedral Co(III) complexes [49].

The Cu(II) complexes exhibited a magnetic moment of 1.88-1.91 B.M which is higher than that of the spin-only value (1.73 BM) [50]. The strong and weak field complexes of some transition metal ions differ in the number of unpaired electrons in the complex, when this number can be ascertained readily from a comparison of the measured magnetic moment and that calculated from the spin paired and spin-free complexes. Determination of the number of unpaired electrons can also give information regarding the 

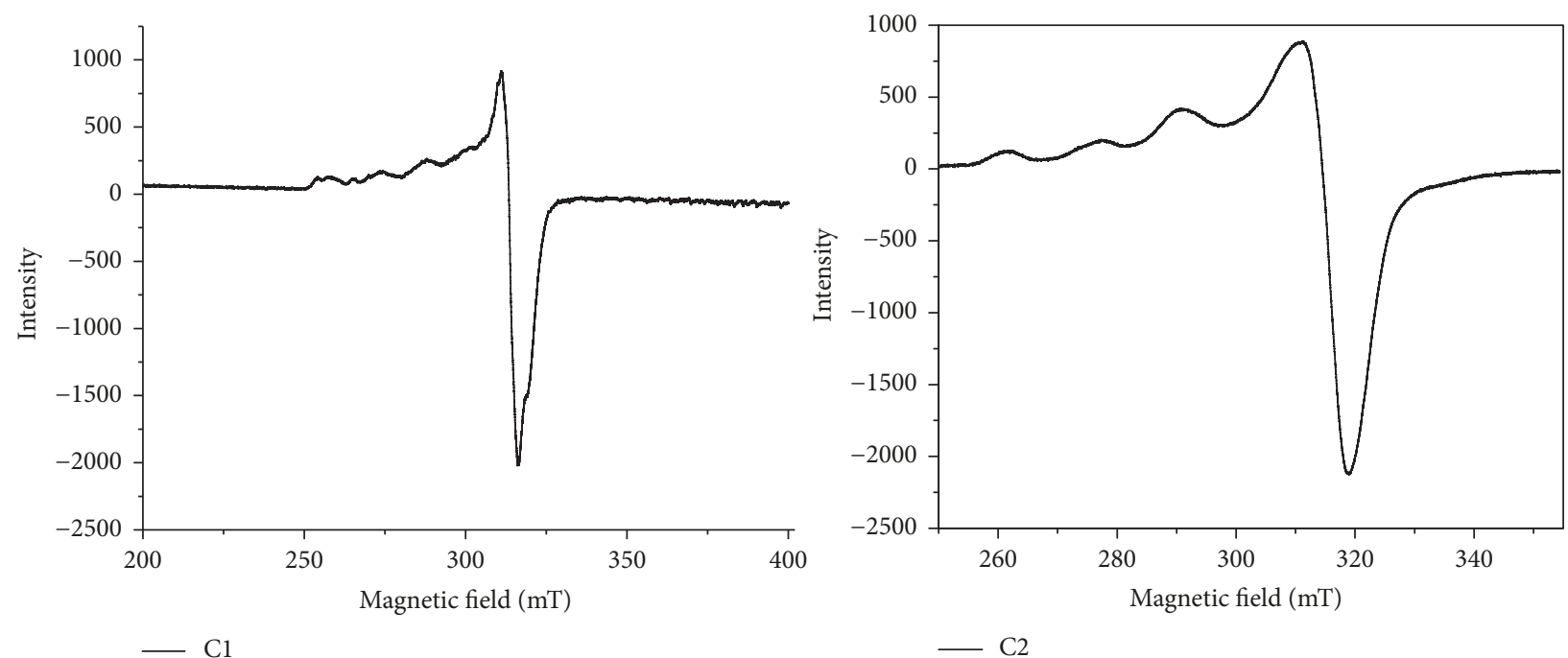

Figure 2: EPR spectrum of complexes $\mathrm{C}_{1}$ and $\mathrm{C}_{2}$.

oxidation state of a metal ion in a complex. It is also useful in establishing a structure of many complexes [51]. Octahedral geometry around the $\mathrm{Cu}(\mathrm{II})$ ion is supported by the magnetic susceptibility value (1.83 BM).

On the other hand, the magnetic moment was not found for the Co(III) complexes, which reveals low-spin $\mathrm{d}^{6}$ diamagnetic environment of the complexes [52]. Thus, magnetic moment values and spectral data support octahedral geometry for both the $\mathrm{Cu}(\mathrm{II})$ and $\mathrm{Co}(\mathrm{III})$ complexes.

3.2.3. Thermogravimetric (DTA-TG) Studies. To give more insight into the thermal stability and compositional analysis of the metal complexes, the thermogravimetric analysis is carried out from ambient temperature to $700^{\circ} \mathrm{C}$. Thermograms of complexes $\left(\mathrm{C}_{1}-\mathrm{C}_{4}\right)$ are presented in Figure S3. The first phase corresponds to the loss of a lattice/coordinated water molecule at $82-120^{\circ} \mathrm{C}$. The second step refers to the decomposition of a ligand molecule to an endothermic process that leads to the formation of a metal oxide above $560^{\circ} \mathrm{C}$ as a final product. Complexes $\left(\mathrm{C}_{2}\right.$ and $\left.\mathrm{C}_{4}\right)$ containing phenanthroline showed decomposition at temperatures lower than that of the ligand. The percentage of metal oxide content was calculated from the weight of the ash obtained.

Thermogravimetric details of the synthesized compounds are presented in Table S2. Generalized thermal degradation pattern of the complexes is represented as follows:

$$
\begin{gathered}
\mathrm{M}\left(\mathrm{L}_{1}\right)(\mathrm{Phen})\left(\mathrm{H}_{2} \mathrm{O}\right)(\mathrm{Cl}) \frac{-\left(\mathrm{H}_{2} \mathrm{O}\right) \text { and } /(\mathrm{Cl})}{82-125^{\circ} \mathrm{C}} \underset{ }{2008-265^{\circ} \mathrm{C} /-\mathrm{Phen}} \\
\text { where, } \mathrm{M}=\mathrm{Cu}(\mathrm{II}) \text { and } \mathrm{Co}(\mathrm{III}) . \quad \mathrm{M}\left(\mathrm{L}_{1}\right)(\mathrm{Phen})
\end{gathered}
$$

The preceding observations further support the composition of the complexes, which is compatible with the results obtained by other methods.
3.2.4. EPR Spectra. X-band EPR spectra of copper complexes $\mathrm{C}_{1}$ and $\mathrm{C}_{2}$ exhibited axial patterns of four lines due to the hyperfine coupling of the unpaired electrons with the copper nucleus $\left({ }^{63} \mathrm{Cu}, I=3 / 2\right)$. The $g$ and $A$ values were calculated from the spectra of the $\mathrm{Cu}$ (II) complexes (Figure 2). The trend $g_{\|}>g_{\perp}$ (Table S3) observed in these complexes indicates that the $\mathrm{Cu}(\mathrm{II})$ is in a distorted octahedral coordination environment, and the unpaired electron most likely resides predominantly in the $\mathrm{d}_{x^{2}-y^{2}}$ orbital $\left(g_{\|}>g_{\perp}>2.0\right)$ of the $\mathrm{Cu}(\mathrm{II})$ ion and is the characteristic feature for the axial symmetry. The deviation of " $g$ " values from the free electron value (2.0023) is by angular momentum contribution in the complexes. The average " $g$ " value for overall distortion is calculated using the equation: $g_{\text {avg }}=(1 / 3)\left(2 g_{\perp}+g_{\|}\right)$[53].

Molecular orbital coefficients in-plane $\sigma$-bonding $\left(\alpha^{2}\right)$, in-plane $\pi$-bonding $\left(\beta^{2}\right)$, and out-of-plane $\pi$-bonding $\left(\gamma^{2}\right)$ are the covalency parameters for the metal to ligand bond which were evaluated using the following expressions:

$$
\begin{aligned}
\alpha^{2}= & \left(\frac{A_{\|}}{0.036}\right)+\left(g_{\|}-2.0027\right)+\frac{3}{7}\left(g_{\perp}-2.0023\right) \\
& +0.04 \\
\beta^{2}= & \frac{\left(g_{\|}-2.0023\right) E}{-8 \lambda \alpha^{2}} \\
\gamma^{2}= & \frac{\left(g_{\|}-2.0023\right) E}{-2 \lambda \alpha^{2}},
\end{aligned}
$$

where $\lambda=-829 \mathrm{~cm}^{-1}$ for the free copper ion and $E$ is the electronic transition energy.

The observed values of $\alpha^{2}$ and $\beta^{2}$ indicate that the complex has covalent bonding character. The smaller the $\beta^{2}$, the larger the covalency of the bonding. Furthermore, it has appeared that the covalency of the out-of-plane is greater than of the in-plane $\pi$-bonding. 


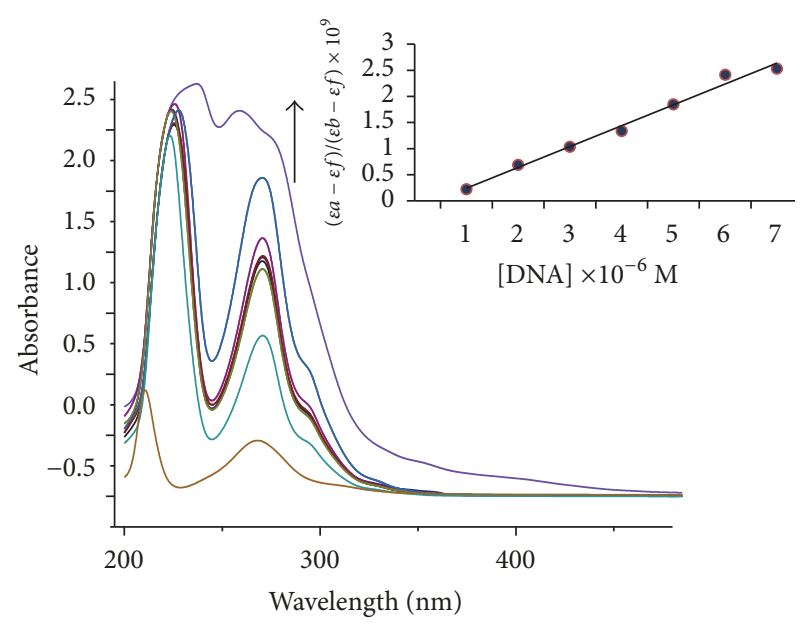

Figure 3: Electronic absorption spectrum of complex $\mathrm{C}_{2}(20 \mu \mathrm{M})$ in the absence and presence of DNA in Tris/ $\mathrm{NaCl}$ buffer $(\mathrm{pH}=7.2)$. The arrows show the absorbance changes upon increasing concentration of DNA $(0-25 \mu \mathrm{M})$ at RT. Inset: plot of $[\mathrm{DNA}] /\left(\varepsilon_{a}-\varepsilon_{f}\right) \times 10^{-5}$ versus [DNA].

The octahedral Co(III) complexes have diamagnetic ground state and the electronic configuration is $t_{2} g^{6}$ and the spin state is $S=0$; for this state, no EPR signal is obtained.

\subsection{Combining Capacity of Metal Complexes with CT-DNA}

3.3.1. Electronic Absorption Spectral Features of DNA Binding. The binding behavior of double-stranded CT-DNA helix with $\mathrm{Cu}$ (II) and $\mathrm{Co}$ (III) complexes was studied using spectral absorption titration followed by the changes in the absorbance and shift in wavelength. The absorption intensity of the complexes was affected resulting in the tendency of hyperchromism (in the range of 224-270 $\mathrm{nm}$ ) and no red shift (small shift $\sim 2 \mathrm{~nm}$ for $\mathrm{C}_{2}$ ) and no sharp isosbestic points on the concomitant addition of DNA to the fixed concentration of complexes were observed. The absorption band was observed at $\lambda_{\max } 266,270,224$, and $268 \mathrm{~nm}$ for $\mathrm{C}_{1}$, $\mathrm{C}_{2}, \mathrm{C}_{3}$, and $\mathrm{C}_{4}$, respectively (Figure 3 ).

The complex can be anticipated to engage bases in the grooves by $\pi-\pi$ interactions (through the planar, aromatic phen moiety) and, meanwhile, form hydrogen bonding and/or electrostatic interactions with the negatively charged phosphate backbone [54]. These spectroscopic changes assured that the complexes have greater binding propensity with DNA helices. Such surface contact was substantiated by quantitative calculations from (1) for their intrinsic binding constant $\left(K_{b}\right)$ and the obtained values are $6.01 \times 10^{4}, 8.16$ $\times 10^{5}, 5.95 \times 10^{4}$, and $7.86 \times 10^{4}$ for complexes $C_{1}, C_{2}$, $\mathrm{C}_{3}$, and $\mathrm{C}_{4}$, respectively, which is comparable to a potential intercalator (for $\mathrm{EB}$ whose $K_{b}$ have been found to be in the order of $10^{6}-10^{7} \mathrm{M}^{-1}$ ) $[55,56]$. These results suggest an intimate association of the compounds with CT-DNA and it is also likely that compounds bind to the duplex helix via external contact (surface binding). The relative $K_{b}$ value and pronounced hyperchromism of complexes $\mathrm{C}_{2}$ and $\mathrm{C}_{4}$ in comparison to $\mathrm{C}_{1}$ and $\mathrm{C}_{3}$, with respect to CTDNA, were because the planar and larger surface area of the 1,10-phenanthroline ring appended in the complex causes enlargement of size of the DNA [57].

3.3.2. Investigation on Quenching Mechanism. Fluorescence quenching propensity further examined the relative binding of compounds to CT-DNA due to high sensitivity and selectivity of this method. A significant decrease in fluorescence intensity of EB-DNA upon gradual addition of compounds at $\lambda_{\text {em }} 626 \mathrm{~nm}$ was observed. Figure 4 confirms this trend. The fluorescence quenching of the EB-DNA solution could be due to relative complexes accepting excited state electron from EB. In addition, it was found that the interaction between complexes and double-stranded DNA in a groove binding mode causes a strong fluorescence quenching.

The Stern-Volmer quenching constant $\left(K_{\mathrm{sv}}\right)$ and Scatchard analysis were accomplished using corrected fluorescence data taking into account the effect of dilution. Deducing from the slope of the quenching plot of relative fluorescence intensity for CT-DNA as a function of the compounds of different concentrations (Figure 4 inset graph), DNA-binding tendency can be reflected in the relative order: Copper complexes $\left(K_{\mathrm{sv}}=\mathrm{C}_{1} 2.55 \times 10^{4}, \mathrm{C}_{2} 3.83 \times 10^{5}\right)>$ cobalt complexes $\left(K_{\mathrm{sv}}=\mathrm{C}_{3} 1.12 \times 10^{4}, \mathrm{C}_{4} 3.61 \times 10^{4}\right)$. This observation suggests that the complexes bind to DNA in a different degree which coincides with their solid structure where complex $\mathrm{C}_{2}$ has the largest plane coordinated to an ancillary phenanthroline ligand. Higher $K_{\mathrm{sv}}$ value of $\mathrm{C}_{2}$ complex suggests its stronger quenching ability than other complexes.

The linear fitting plots of $\log \left[\left(F_{0}-F\right) / F\right]$ versus $\log [Q]$ (Figure 5) from (3) furnished the values of intrinsic binding constant $\left(K_{b}\right)$ in the magnitude of $10^{4}-10^{5}$, suggesting that the compounds bind strongly to DNA and the binding sites (n) were found to be $0.8-1.9 \pm 0.15$. Comparable association of complexes to the DNA base with classical intercalator, EB $\left(K_{b}=10^{7} \mathrm{M}^{-1}\right)$, assisted for the hypothesis of compounds to be minor groove binding which is almost similar to reported benzothiazole complexes [58]. The significant superior binding of $\mathrm{C}_{2}$ and $\mathrm{C}_{4}$ compared to other complexes is possibly owing to the 1,10-phenanthroline ring analogue as coligand in the respective complexes, which favours the interaction with the DNA through $\pi-\pi^{*}$ interaction and H-bonding [59].

3.3.3. Viscosity Measurements. The most rigorous mean of testing the binding mode between DNA and compounds is viscometry technique in solution in the absence of crystallographic structural data. A classical intercalation probe demands that the DNA helix must be lengthened as base pairs are separated to accommodate the binding ligand, which leads to an increase in DNA viscosity [60]. EB, a well-known DNA intercalator, increases the relative viscosity strongly by lengthening the DNA double helix through intercalation, while DAPI, a popular groove binding agent under the same conditions, typically causes less pronounced (positive or negative) or no change in DNA solution which leads to quenching its effective length and concomitantly its viscosity $[61,62]$. Herein, the relative thickness of compounds inapparently 


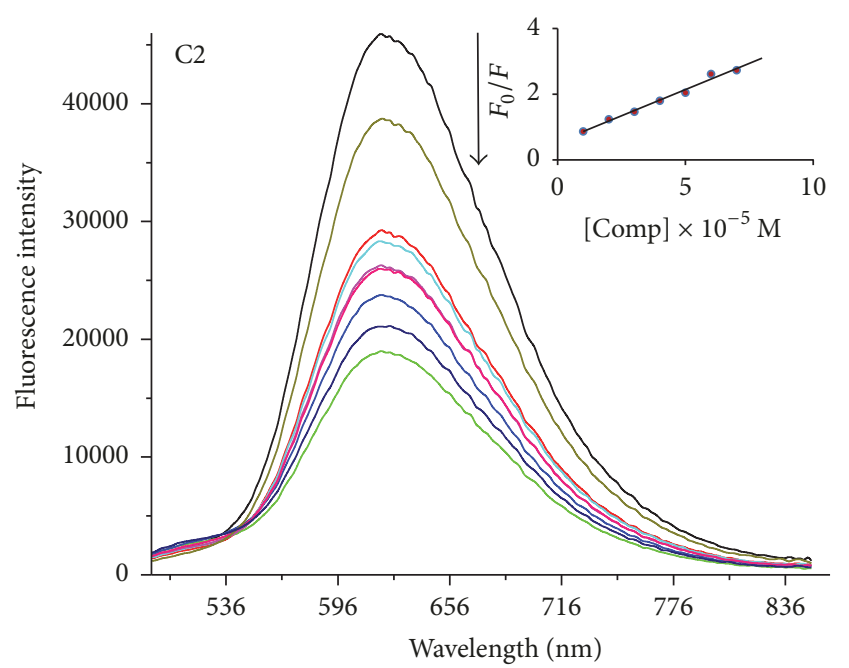

(a)

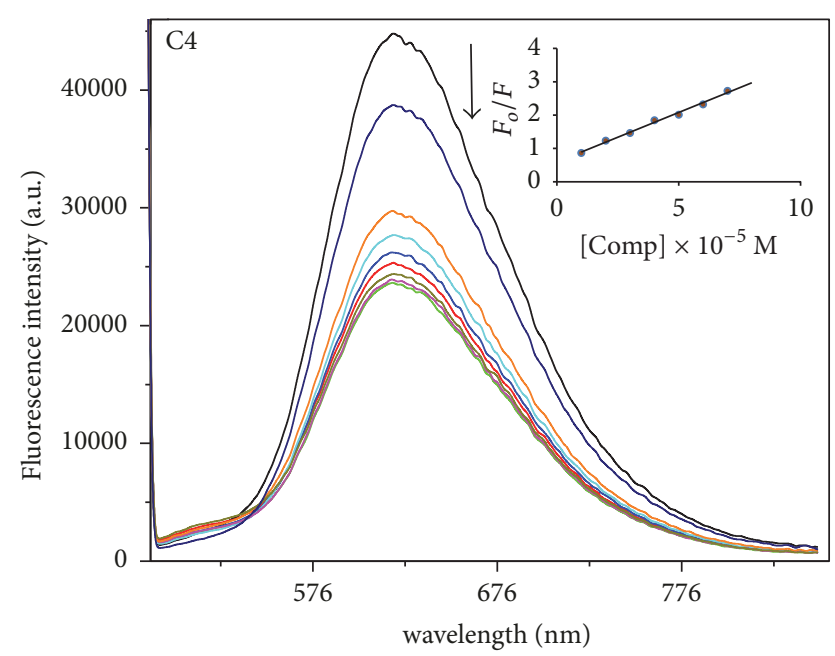

(b)

FIGURE 4: Fluorescence quenching curves of EB-DNA in presence of complex $\left(\mathrm{C}_{2}\right.$ and $\left.\mathrm{C}_{4}\right)$ at the concentration $0-35 \mu \mathrm{M}$ at the interval of 5 in Tris- $\mathrm{HCl} / \mathrm{NaCl}$ buffer ( $\mathrm{pH}$ 7.2). The arrow indicates the effect of increasing the complex concentration on the fluorescence emission of ethidium bromide bound CT-DNA. The inset shows the linear fit of $F_{o} / F$ versus [complex].

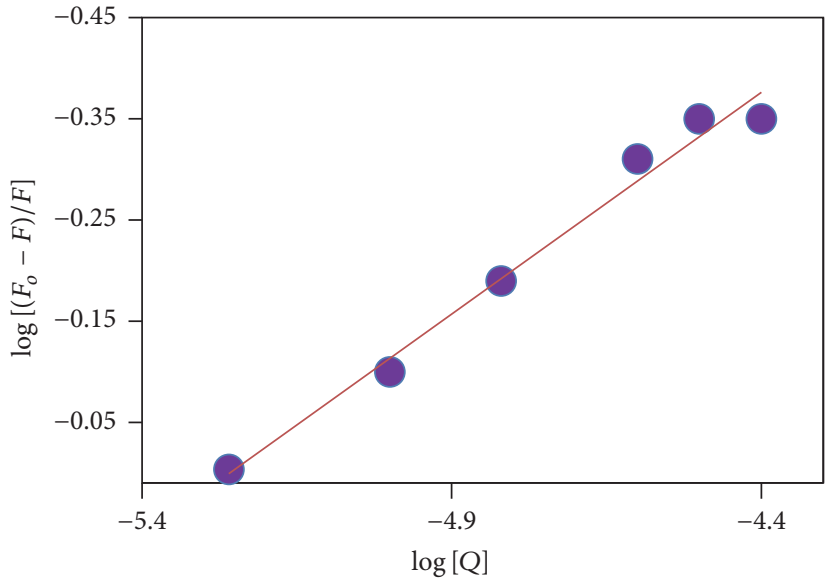

(a)

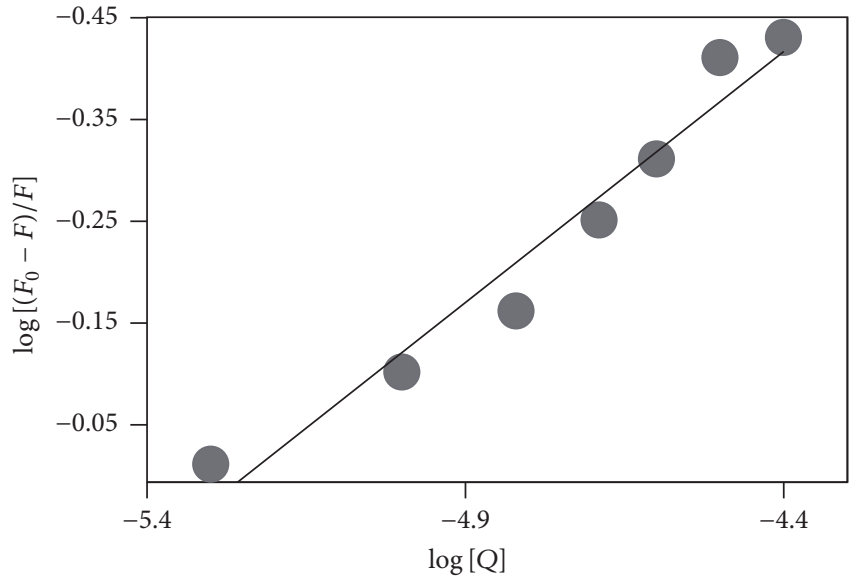

(b)

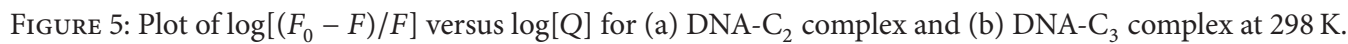

increases upon increasing concentration of compounds unlike the behavior of EB [2]. Interestingly, for $\mathrm{C}_{1}$ and $\mathrm{C}_{3}$ complexes there is an increase in specific viscosity of DNA, which is not as pronounced as the classical EB and the mixed ligand complexes. The degree of viscosity depends on the binding affinity to DNA which is calculated by (3) which follows the order $\mathrm{EB}>\mathrm{C}_{2}>\mathrm{C}_{4}>\mathrm{C}_{1}>\mathrm{C}_{3}>$ DAPI. The results suggest that the complexes could bind to DNA primarily groove binding nature which is consistent with preceding electronic and fluorescence spectroscopic results. The effects of relative viscosity of CT-DNA under the influence of increasing amounts of the complexes at $27 \pm 0.1^{\circ} \mathrm{C}$ are depicted in Figure 6.
3.4. Chemical Nucleus Activity. Plasmid DNA strand scission was achieved by monitoring the gel electrophoresis for naturally occurring, covalently supercoiled conformation (Form I, SC) of pUC18 DNA transition to the open circular (Form II, OC) and linear conformation (Form III, LC). Different DNA nuclease capacity of complexes may occur due to different binding affinities of the complexes to DNA. The DNA cleaving abilities of all the compounds were investigated by reaction changes with supercoiled (SC) pUC18 DNA and the relative mobility of the products on agarose gel. At first, the concentration-dependent DNA cleavage by the complexes was performed on plasmid pUC18 DNA in Tris $\mathrm{pH}$ 7.1 buffer solutions in the absence of any reducing agents. The 


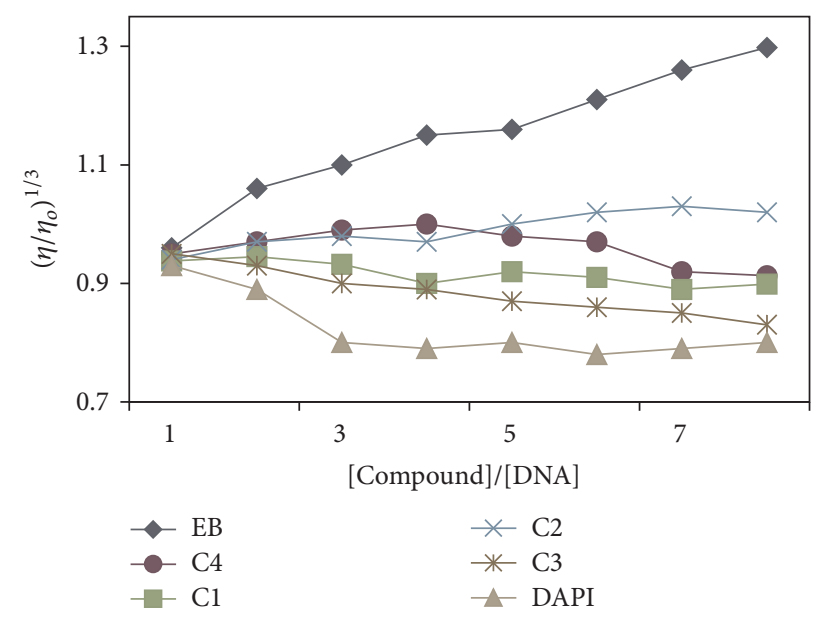

FIGURE 6: Effects of relative viscosity of CT-DNA under the influence of increasing amount of the complexes at $27 \pm 0.1^{\circ} \mathrm{C}$.

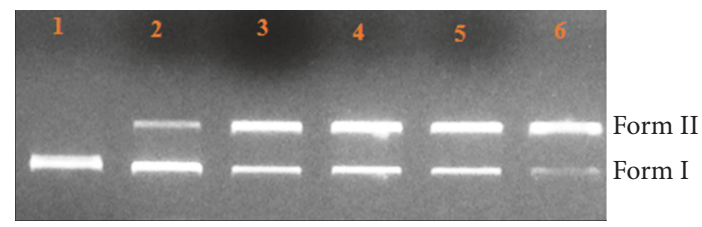

FIGURE 7: Gel electrophoresis assay for the cleavage of pUC18 plasmid DNA (200 ng) by $\mathrm{C}_{2}$ in $50 \mathrm{mM}$ Tris- $\mathrm{HCl} / \mathrm{NaCl}$ buffer $(\mathrm{pH}$, 7.3) after $45 \mathrm{~min}$ incubation time at different concentration; Lane 1, DNA control; Lane 2, DNA $+\mathrm{C}_{2}(10 \mu \mathrm{M})$; Lane 3: DNA $+\mathrm{C}_{2}$ $(20 \mu \mathrm{M})$; Lane 4 : DNA $+\mathrm{C}_{2}(30 \mu \mathrm{M})$; Lane 5: DNA $+\mathrm{C}_{2}(40 \mu \mathrm{M})$; Lane 6: DNA $+\mathrm{C}_{2}(50 \mu \mathrm{M})$.

electrophoretic pattern of the DNA cleavage (Figure 7) shows that the gradual cleavage observed by the complexes in the range of $10-50 \mu \mathrm{M}$. Meanwhile, the complex acts as chemical nucleases by cleaving the DNA Form I into Form II and the intensity of Form II increases as the compound concentration increases. Enhanced concentration of compound induces DNA cleavage more efficiently, which was monitored by the appearance of Form II with the disappearance of Form I.

Mechanistic Pathway of DNA Cleavage by Reactive Oxygen Species. Copper and cobalt complexes can cleave DNA through an oxidative or hydrolytic mechanism. In the process of oxidative DNA scission, it may lead to the formation of reactive species like hydroxyl radical $\left(\mathrm{HO}^{*}\right)$, superoxide anion radical $\left(\mathrm{O}_{2}{ }^{-\bullet}\right)$, and/or singlet oxygen $\left({ }^{1} \mathrm{O}_{2}\right)$ which cause damage to the base or/and sugar of DNA. To establish the effect of reactive species on cleavage efficiency of pUC18 DNA induced by metal complexes, comparative DNA nicking ability of all the complexes was evaluated in the presence of $\mathrm{H}_{2} \mathrm{O}_{2}$, 3-mercaptopropionic acid (MPA), and ascorbic acid (Asc) (Figure 8, Lanes 2-4). DNA nuclease activity was significantly increased in presence of oxidative reagents which follows the order MPA $>\mathrm{H}_{2} \mathrm{O}_{2}>$ Asc. Thus, complexes with MPA showed effective cleavage activity, thus by producing $\mathrm{SH}$

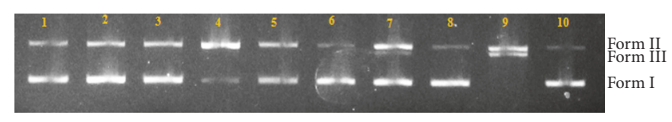

(a)

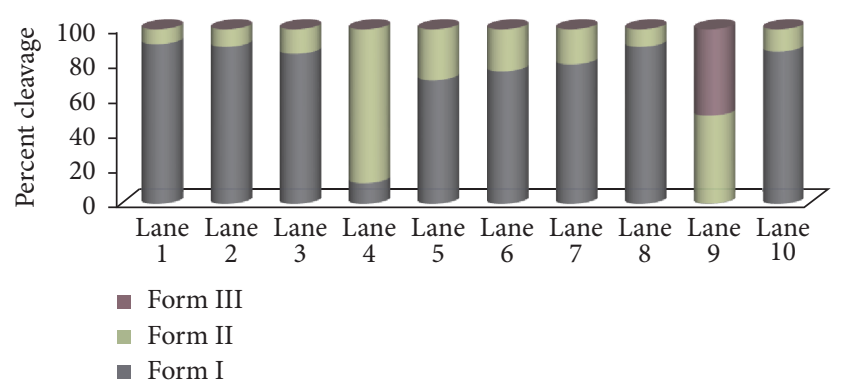

(b)

FIGURE 8: (a) Agarose-gel electrophoresis diagram showing cleavage of pBR322 supercoiled DNA ( $200 \mathrm{ng}$ ) by complex 2 in presence of activators and reactive oxygen species at $310 \mathrm{~K}$ after incubation for $45 \mathrm{~min}$. Lane 1: DNA control; Lane 2: DNA + $\mathrm{C}_{2}+$ Asc $(0.4 \mathrm{M})$; Lane 3: DNA $+\mathrm{C}_{2}+\mathrm{H}_{2} \mathrm{O}_{2}(0.4 \mathrm{M})$; Lane 4: DNA $+\mathrm{C}_{2}+\mathrm{MPA}$ $(0.4 \mathrm{M})$; Lane 5: DNA + $\mathrm{C}_{2}+\mathrm{DMSO}(0.4 \mathrm{M})$; Lane 6: DNA $+\mathrm{C}_{2}$ $+\mathrm{EtOH}(0.4 \mathrm{M})$; Lane 7: DNA $+\mathrm{C}_{2}+\mathrm{NaN}_{3}(0.4 \mathrm{M})$; Lane 8: DNA $+\mathrm{C}_{2}+\mathrm{SOD}$ (15 units); Lane 9: DNA $+\mathrm{C}_{2}+$ methyl green $(2.5 \mu \mathrm{L}$ of $0.01 \mathrm{mg} / \mathrm{ml}$ solution); Lane 10: DNA $+\mathrm{C}_{2}+$ DAPI $(8 \mu \mathrm{M})$. (b) A graph of percentage cleavage of DNA determined using image analyzer.

radical leads complete degradation of Form I to Form II was noticed which suggests that these activators play a crucial role in assisting complexes in DNA cleavage.

Gel electrophoretic study was carried out with some standard diffusible radical scavengers such as hydroxyl radical scavengers DMSO, EtOH, singlet oxygen quencher-sodium azide, and superoxide radical scavenger as SOD which were used prior to the addition of complex to DNA solution under the aforesaid identical conditions. The addition of $\mathrm{DMSO} / \mathrm{EtOH}$ to complex solution inhibited the DNA cleavage efficiency (Lanes 5 and 6) which is an indicative of the involvement of diffusible (HO) hydroxyl radicals as one of the ROS accountable for DNA nicking, while the addition of SOD decreased the cleavage efficiencies (Lane 7) which revealed that superoxide radical was likely to be the cleaving agent. However, there was an enhancement of DNA cleavage in case of $\mathrm{NaN}_{3}$ (Lane 8) followed by the appearance of NC (Form II) which demonstrated the noninvolvement of sodium azide suggestive nonactivated oxygen intermediate in DNA scission process. The complexes $\mathrm{C}_{2}$ and $\mathrm{C}_{4}$ can convert SC into NC and LC efficiently compared to $\mathrm{C}_{1}$ and $\mathrm{C}_{3}$ which implies that the metal complexes induced intensively the plasmid DNA cleavage where SOD anion, as well as oxidative mechanistic pathways, can play a significant role in the cleavage pattern. The observed cleavage efficiency follows the order of complex $2>4>1>3$, depending upon the coligand. It is also noticed that the hydrophobicity of mixed ligand complex (strong interaction of the extended aromatic rings of the phen moiety) induces efficient cleavage. 
DNA Cleavage in the Presence of Recognition Elements. The groove binding preference of the complexes was studied using DNA minor groove-binder 4 '-6-diamidino-2-phenylindole (DAPI) and major groove-binder methyl green (MG). The supercoiled pUC18 DNA was treated with DAPI or methyl green before complexes addition.

The electrophoresis results obtained with DAPI (Lane 10, Figure 8) are followed by concomitant conversion of Form I to Form II/III in all the complexes. However, no apparent inhibition of DNA damage was observed in presence of major groove-binder MG (Lane 9, Figure 8). This further strengthens the hypothesis of minor groove preference for the complexes. These results are of significance as majority of the oxidative cleavage reagents usually bind in the minor groove mode [61].

The complexes exhibit moderate cleavage activity in the following order: $2>4>1>3$.

3.5. SOD Assay. One of the essential biological properties of metal complexes is radical scavenging activity. There is a linear relationship between DNA binding and antioxidant properties of the compounds. Radical scavenging activity of prepared compounds was determined indirectly by the nitroblue tetrazolium (NBT) assay. Generation of superoxide radicals is determined by the percentage of inhibition of the reduction of NBT $\left(\mathrm{IC}_{50}\right)$. It has been revealed (Table S4) that the synthesized copper complexes exhibited quite a strong antioxidant activity in the range of $0.13-1.02 \mu \mathrm{mol} \mathrm{dm}{ }^{-3}$ with reference to the standard used. The significant $\mathrm{IC}_{50}$ values are determined by UV-Vis spectroscopy. The scavenging effect of the $\mathrm{Co}$ (III) complexes may be ascribed to the chelating function of a ligand with the metal ion to achieve significantly selective effect of radical scavenging activity in biological system [63]. It has been proposed that only complexes with $\mathrm{IC}_{50}$ values below $20 \mu \mathrm{M}$ may become clinically interesting [28]. Table S4 reveals the superoxide radical suppression efficacies of the complexes. It was observed that the radical scavenging activities of complexes increased with the increment of the complex concentrations.

3.6. Evaluation of Antimicrobial Activity. MIC data (Table 1) display varying degrees of biocidal effects of $\mathrm{L}_{1}$ and its complexes on the growth of tested species. This study highly encourages that all the metal complexes have higher inhibitory effects than free ligand, and in particular mixed ligand complexes exhibited prominent antimicrobial activity, observed in the order of $\mathrm{C}_{2}>\mathrm{C}_{4}>\mathrm{C}_{1}>\mathrm{C}_{3}>\mathrm{L}_{1}$. All of these synthesized compounds showed MIC values in micromolar range $(3.02-19.23 \mu \mathrm{g} / \mathrm{mL})$. Out of these, $C_{2}$ is the most bioactive (MIC $3.025 \mu \mathrm{g} / \mathrm{mL}$ ) in the series and it was found to be more potent than the standard drug (MIC $3.12 \mu \mathrm{g} / \mathrm{mL}$ ). The augmented toxicity of all the metal complexes could be explained on the light of Overtone's concept [64] and Tweedy's chelation theory [65]. As per these theories, the mode of action of the metal complexes may involve the formation of hydrogen bond formation through the azomethine group $(\mathrm{HC}=\mathrm{N}-)$ with the active centers of cell constituents [66] resulting in interferences with the
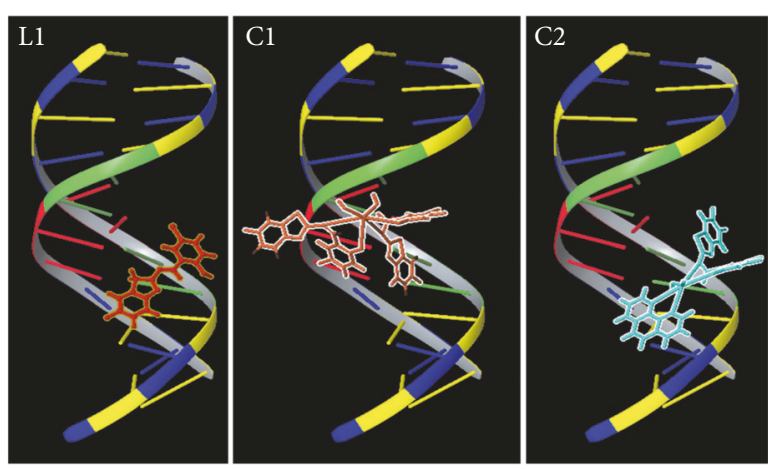

FIGURE 9: Binding mode of CT-DNA with compounds $\left(\mathrm{L}_{1}, \mathrm{C}_{1}\right.$, and $\mathrm{C}_{2}$ ). DNA is represented in ribbon structure wherein the nucleoside is colored as yellow-guanine, maroon-thymine, blue-cytosine, and light green as adenine. Compounds are represented and highlighted in the figure.

normal cell process. Structural activity relationship (SAR) study of the benzothiazole compounds shows that electron withdrawing groups (EWD) like fluorine exerts more potent antibacterial activity than electron donating groups (ER) is reported [67].

3.7. Molecular Docking Studies. All the compounds were subjected to molecular docking with DNA and $\mathrm{Cu}, \mathrm{Zn}-\mathrm{SOD}$ using glide module of Schrödinger software to explore the binding of compounds with DNA. The virtual predicted topranking conformation with minimum energy glide score of compounds suggests best possible geometrical oriental binding with the target DNA double helix, which implies the highest binding affinity of DNA. The order of binding of compounds is as follows: $\mathrm{L}_{1}(-3.157), \mathrm{C}_{2}(-3.564), \mathrm{C}_{4}$ (-3.624), $\mathrm{C}_{1}(-4.288)$, and $\mathrm{C}_{3}(-4.195)$, whereas, with $\mathrm{Cu}$, it is $\mathrm{Zn}-\mathrm{SOD} \mathrm{C}_{1}(-2.474), \mathrm{C}_{2}(-1.478), \mathrm{C}_{3}(-3.013)$, and $\mathrm{C}_{4}$ $(-3.469)$. The other associated parameter calculated during docking studies is van der Waals interactions $(\mathrm{kcal} / \mathrm{mol})$ for DNA [ $\mathrm{L}_{1}$ (-25.097), $\mathrm{C}_{2}$ (-21.049), $\mathrm{C}_{4}$ (-22.156), $\mathrm{C}_{1}$ (-27.888), and $\left.\mathrm{C}_{3}(-28.739)\right]$ as well as $\mathrm{Cu}, \mathrm{Zn}-\mathrm{SOD}\left[\mathrm{C}_{1}(-25.833), \mathrm{C}_{2}\right.$ $(-12.897), C_{3}(-35.912)$, and $\left.C_{4}(-33.996)\right]$. The determined $3 \mathrm{D}$ structure of $\mathrm{C}_{1}$ plays a significant role in exploring its structural consequences and conformational behavior during interactions with DNA [68]. $\mathrm{C}_{1}$ and $\mathrm{C}_{3}$ stacked with A-Trich regions, whereas $\mathrm{C}_{2}, \mathrm{C}_{4}$, and $\mathrm{L}_{1}$ bind with $\mathrm{G}-\mathrm{C}$ residues of groove wall of DNA by surface binding interactions (Figure 9). Geometrical oriental binding of $\mathrm{L}_{1}$ and $\mathrm{C}_{2}$ appears to be the same (Figure 9). Ligand $\mathrm{L}_{1}$ interacts with guanine and adenine through $\pi-\pi$ interaction (Figure 10(a)). Complex $\mathrm{C}_{1}$ interacts with adenine via salt bridge and hydrogen bond (Figure 10(b)), whereas $C_{2}$ interacts with adenine via salt bridge along with $\pi-\pi$ interaction and hydrogen bond (Figure 10(c)); thus it shows maximum affinity with adenine. Thus, these confer the highest binding affinities of complexes $\mathrm{C}_{2}$ and $\mathrm{C}_{4}$ with DNA. Hence, these docked complexes, intra- and intermolecular hydrogen bond, and hydrophobic interactions $\left(\mathrm{C}_{2}, \mathrm{C}_{4}\right.$, and $\left.\mathrm{L}_{1}\right)$ significantly participated in maintaining the stacked position of the complexes with DNA 


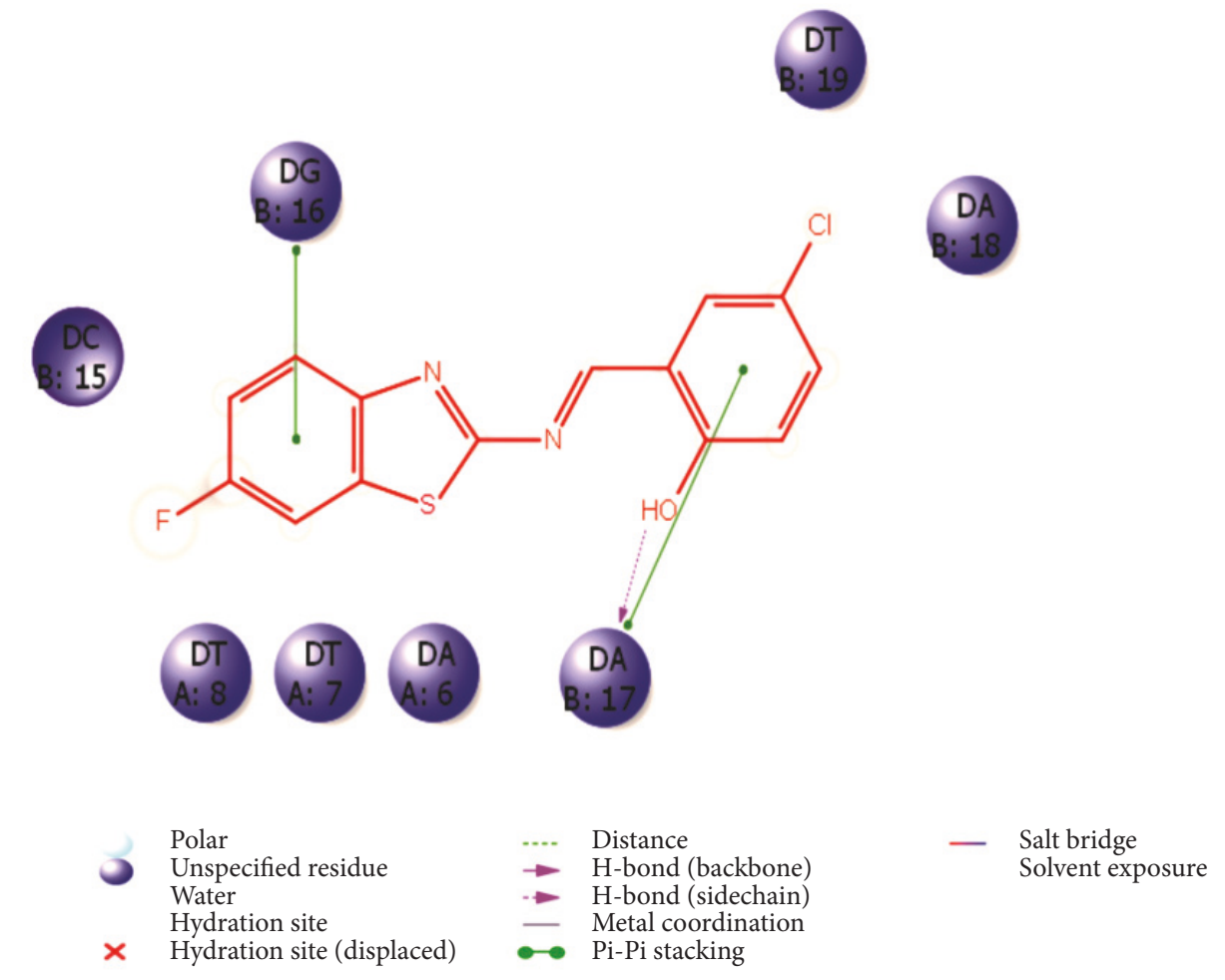

(a)

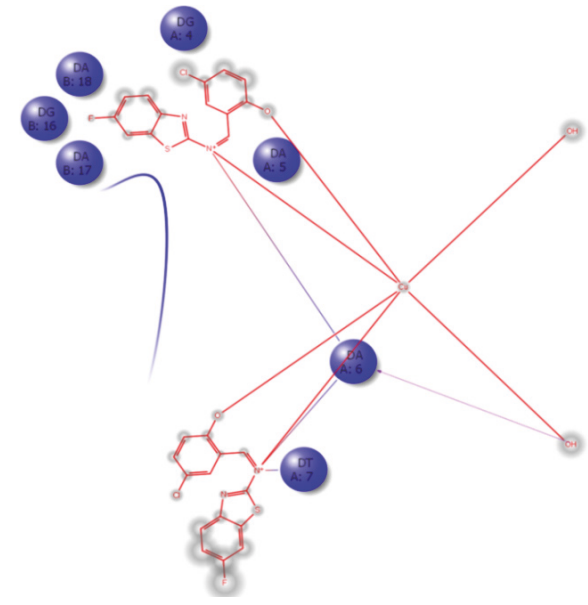

(b)

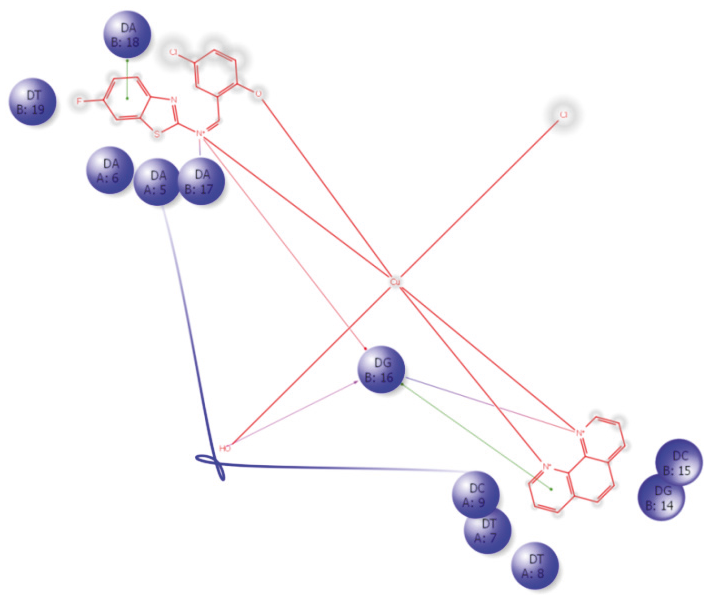

(c)

FIgURE 10: Two-dimensional views of docked complexes.

[68]. Therefore, it is suggested that there is a mutual complement between spectroscopic data and molecular docked model, which can be authenticated with spectroscopic results and it also provides the indication of groove mode.

Docked structures of DNA with $\mathrm{L}_{1}$ (Figure 10(a)), $\mathrm{C}_{1}$ (Figure 10(b)), and $\mathrm{C}_{2}$ (Figure 10(c)) showing the molecular interactions like inter- and intrahydrogen bonds, $\pi-\pi$ stacking, and salt bridges.

Binding of compound at $\mathrm{Cu} \mathrm{Zn}$ domain of SOD results in an increase in an antioxidant activity of SOD and decrease in oxidative stress [69]. All the compounds were found near active site of $\mathrm{Cu}, \mathrm{Zn}-\mathrm{SOD}$ (Figure 11), and $\mathrm{C}_{4}$ interacted with Tyr108 via $\pi-\pi$ stacking, whereas $C_{1}$ formed hydrogen bond with Ser109, $C_{2}$ with Arg113, and $C_{3}$ interacted with Glu107 via salt bridge. Hence, the data suggest that these compounds have potent binding with Argl13 and Glu107 which are resided near active site of $\mathrm{Cu}, \mathrm{Zn}$-SOD, thereby regulating the generation of free radicals.

\section{Conclusions}

The newly synthesized four mononuclear copper and cobalt complexes of imine-based ligand $\left(\mathrm{L}_{1}\right)$ were analyzed with spectral techniques and screened in vitro for their binding 
TABLE 1: Antimicrobial activities of synthesized compounds.

\begin{tabular}{lccccccc}
\hline $\begin{array}{l}\text { Sl. } \\
\text { number }\end{array}$ & $\begin{array}{c}\text { Compounds } \\
(30 \mu \mathrm{g} / \mathrm{disk})\end{array}$ & E. coli & P. aeruginosa & B. subtilis & S. aureus & C. albicans & A. niger \\
\hline$(1)$ & $\mathrm{L}_{1}$ & $11.0(15 \pm 0.6)$ & $12.6(17 \pm 0.3)$ & $12.3(18 \pm 0.9)$ & $11.9(17 \pm 0.1)$ & $19.6(12 \pm 0.2)$ & $19.2(16 \pm 0.4)$ \\
$(2)$ & $\mathrm{C}_{1}$ & $4.7(22 \pm 0.7)$ & $4.8(22 \pm 0.9)$ & $4.8(23 \pm 0.6)$ & $4.6(22 \pm 0.7)$ & $11.3(20 \pm 0.4)$ & $11.5(20 \pm 0.6)$ \\
$(3)$ & $\mathrm{C}_{2}$ & $3.02(24 \pm 0.4)$ & $3.45(24 \pm 0.5)$ & $3.31(24 \pm 0.4)$ & $3.39(21 \pm 0.9)$ & $8.84(26 \pm 0.2)$ & $8.92(26 \pm 0.5)$ \\
$(4)$ & $\mathrm{C}_{3}$ & $4.4(22 \pm 0.6)$ & $4.6(21 \pm 0.6)$ & $4.46(24 \pm 0.6)$ & $3.91(22 \pm 0.6)$ & $10.6(23 \pm 0.6)$ & $9.37(25 \pm 0.6)$ \\
$(5)$ & $\mathrm{C}_{4}$ & $3.73(22 \pm 0.8)$ & $3.71(23 \pm 0.8)$ & $3.13(25 \pm 0.1)$ & $3.64(26 \pm 0.8)$ & $9.16(24 \pm 0.5)$ & $9.42(24 \pm 0.4)$ \\
$(6)$ & Ciprofloxacin & $3.12(20 \pm 0.6)$ & $3.12(20 \pm 0.6)$ & $3.0(27 \pm 0.6)$ & $3.12(19 \pm 0.6)$ & - & - \\
$(7)$ & Fluconazole & - & - & - & - & $6.25(16 \pm 0.6)$ & $6.31(17 \pm 0.6)$ \\
\hline
\end{tabular}

Each value was replicated thrice.

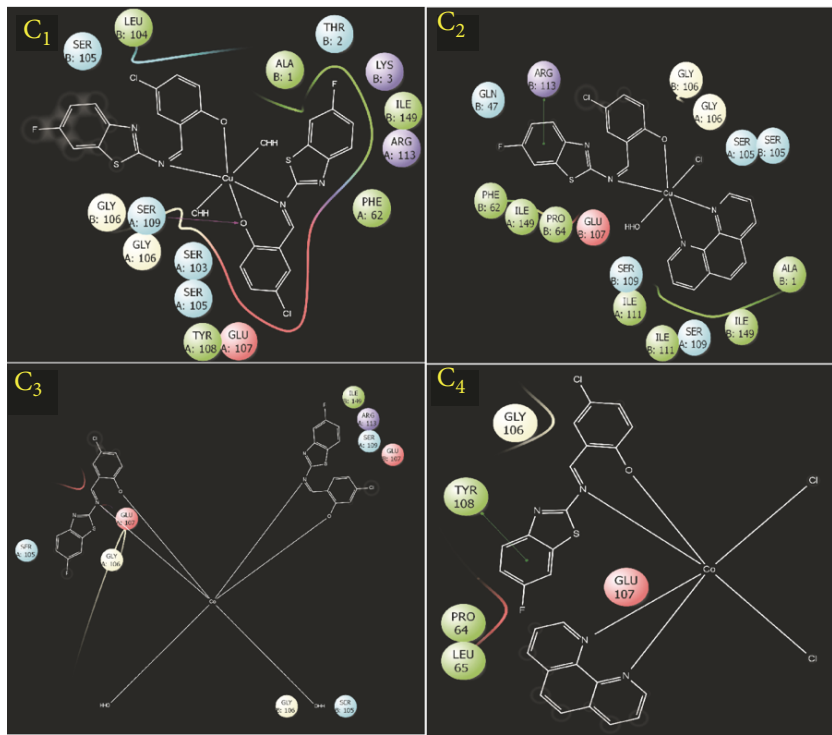

FIgURE 11: Active center for $\mathrm{O}_{2}{ }^{--}$scavenging of metal complexes.

efficacy towards DNA. Taking into account the analytical and spectral studies, an octahedral geometry is assigned to all these complexes. TGA revealed that the synthesized compounds were thermally stable. Spectral titration assessed the relative noncovalent binding of metal complexes to DNA and the results are corroborated with each other techniques. Observed DNA cleavage results demonstrated that their effective interactions with DNA in groove mode depend on ligand architecture. The antioxidant activity of compounds was measured by NBT assay. After binding with metal ions, the scavenging of superoxide anion free radical $\left(\mathrm{O}_{2}{ }^{--}\right)$ activity of metal complexes obviously increased. The copper complexes exhibited the remarkable capacity for scavenging $\mathrm{O}_{2}{ }^{--}$. This is further fortified by molecular docking study where all the compounds are preferential selective for the groove of DNA. Antimicrobial results in higher antibacterial and antifungal potency of metal complexes than free ligand. The presence of a planar heterocyclic ligand in $\mathrm{Cu}$ (II) and $\mathrm{Co}$ (III) drug based mixed-ligand complexes which changes the interaction of complex in biological systems is noticed.

\section{Data Availability}

Supplementary crystallographic data of $\mathrm{L}_{1}$ associated with this article can be found in the online version at http://www .sciencedirect.com/science/article/pii/S0022286017304921 with CCDC no. 1537326.

\section{Conflicts of Interest}

The authors declare that there are no conflicts of interest regarding the publication of this paper.

\section{Acknowledgments}

The author K. Savithri is extending thanks to the University Grant Commission, New Delhi, for the award of Junior Research Fellow under the Rajiv Gandhi National Fellowship Scheme. Also, the authors wish to thank Institute of Excellence, University of Mysore, Vigyan Bhavan, for spectral measurements and IIT, Bombay, for EPR measurements.

\section{Supplementary Materials}

Figure S1: FT-IR spectra of compounds. Figure S2: electronic spectra of complexes with ligand at ambient temperature in DMSO solution. Figure S3: thermogram of $\mathrm{C} 1$ and $\mathrm{C} 4$ complex. Table S1: electronic absorption and magnetic susceptibility data of $\mathrm{L}_{1}$ and its metal complexes. Table S2: TGA analysis of synthesized compounds. Table S3: ESR spectral data of copper(II) complexes. Table S4: results of SOD assay of synthesized complexes. (Supplementary Materials)

\section{References}

[1] T. A. Yousef, O. K. Alduaij, G. M. Abu El-Reash, and R. M. El Morshedy, "Semiempirical studies, spectral analysis, in vitro antibacterial and DNA degradation studies of heterocyclic thiosemicarbazone ligand and its metal complexes," Journal of Molecular Liquids, vol. 222, pp. 762-776, 2016.

[2] P.-X. Xi, Z.-H. Xu, F.-J. Chen, Z.-Z. Zeng, and X.-W. Zhang, "Study on synthesis, structure, and DNA-binding of $\mathrm{Ni}, \mathrm{Zn}$ complexes with 2-phenylquinoline-4-carboylhydrazide," Journal of Inorganic Biochemistry, vol. 103, no. 2, pp. 210-218, 2009. 
[3] T. R. Arun, R. Subramanian, S. Packianathan, and N. Raman, "Fluorescence Titrations of Bio-relevant Complexes with DNA: Synthesis, Structural Investigation, DNA Binding/Cleavage, Antimicrobial and Molecular Docking Studies," Journal of Fluorescence, vol. 25, no. 4, pp. 1127-1140, 2015.

[4] M. R. Gill, H. Derrat, C. G. W. Smythe, G. Battaglia, and J. A. Thomas, "Ruthenium(II) Metallo-intercalators: DNA Imaging and Cytotoxicity," ChemBioChem, vol. 12, no. 6, pp. 877-880, 2011.

[5] V. M. Manikandamathavan, M. Thangaraj, T. Weyhermuller et al., "Novel mononuclear Cu (II) terpyridine complexes: Impact of fused ring thiophene and thiazole head groups towards DNA/BSA interaction, cleavage and antiproliferative activity on HepG2 and triple negative CAL-51 cell line," European Journal of Medicinal Chemistry, vol. 135, pp. 434-446, 2017.

[6] X.-B. Fu, G.-T. Weng, D.-D. Liu, and X.-Y. Le, "Synthesis, characterization, DNA binding and cleavage, HSA interaction and cytotoxicity of a new copper(II) complex derived from 2(2I-pyridyl) benzothiazole and glycylglycine," Journal of Photochemistry and Photobiology A: Chemistry, vol. 276, pp. 83-95, 2013.

[7] P. R. Reddy and A. Shilpa, "Interaction of DNA with small molecules: Role of copper histidyl peptide complexes in DNA binding and hydrolytic cleavage," Indian Journal of Chemistry - Section A Inorganic, Physical, Theoretical and Analytical Chemistry, vol. 49, no. 8, pp. 1003-1015, 2010.

[8] M. Zaki, F. Arjmand, and S. Tabassum, "Current and future potential of metallo drugs: Revisiting DNA-binding of metal containing molecules and their diverse mechanism of action," Inorganica Chimica Acta, vol. 444, pp. 1-22, 2016.

[9] R. S. Keri, M. R. Patil, S. A. Patil, and S. Budagupi, "A comprehensive review in current developments of benzothiazolebased molecules in medicinal chemistry," European Journal of Medicinal Chemistry, vol. 89, pp. 207-251, 2015.

[10] T. S. Base, "Potential antimicrobial properties of two new synthetic metal complexes containing a materials and methods," International Journal of Advanced Research, vol. 3, pp. 12301238, 2015.

[11] S. Aiello, G. Wells, E. L. Stone et al., "Synthesis and biological properties of benzothiazole, benzoxazole, and chromen-4-one analogues of the potent antitumor agent 2-(3,4-dimethoxyphenyl)-5- fluorobenzothiazole (PMX 610, NSC 721648)," Journal of Medicinal Chemistry, vol. 51, no. 16, pp. 5135-5139, 2008.

[12] M. Nalawade, A. Nalawade, M. Patange, and R. Tase, "Thiazole containing schiffs bases and their transition metal complexes," International Journal of Engineering Science Invention, vol. 2, pp. 1-4, 2013.

[13] I. Hutchinson, M.-S. Chua, H. L. Browne et al., "Antitumor benzothiazoles. 14. Synthesis and in vitro biological properties of fluorinated 2-(4-aminophenyl)benzothiazoles," Journal of Medicinal Chemistry, vol. 44, no. 9, pp. 1446-1455, 2001.

[14] N. Vamsikrishna, M. P. Kumar, S. Tejaswi, A. Rambabu, and Shivaraj, "DNA Binding, Cleavage and Antibacterial Activity of Mononuclear $\mathrm{Cu}(\mathrm{II}), \mathrm{Ni}(\mathrm{II})$ and $\mathrm{Co}(\mathrm{II})$ Complexes Derived from Novel Benzothiazole Schiff Bases," Journal of Fluorescence, vol. 26, no. 4, pp. 1317-1329, 2016.

[15] S. M. Ahmadi, "In Vitro Studies on Calf Thymus DNA interaction with Quercetin-Palladium(II) Complex," in Proceedings of the International Conference Bioscience Biochemistry Bioinformatics, vol. 5, pp. 110-113, 2011.
[16] J. Joseph and G. B. Janaki, "Copper complexes bearing 2aminobenzothiazole derivatives as potential antioxidant: Synthesis, characterization," Journal of Photochemistry and Photobiology B: Biology, vol. 162, pp. 86-92, 2016.

[17] M. Hazra, T. Dolai, A. Pandey, S. K. Dey, and A. Patra, "Synthesis and characterisation of copper(II) complexes with tridentate NNO functionalized ligand: Density function theory study, DNA binding mechanism, optical properties, and biological application," Bioinorganic Chemistry and Applications, vol. 2014, Article ID 104046, 13 pages, 2014.

[18] R. A. Khan, M. Usman, R. Dhivya et al., "Heteroleptic Copper(I) Complexes of "scorpionate" Bis-pyrazolyl Carboxylate Ligand with Auxiliary Phosphine as Potential Anticancer Agents: An Insight into Cytotoxic Mode," Scientific Reports, vol. 7, Article ID 45229, 2017.

[19] R. J. Natarajan Raman, "Synthesis, characterization, electrochemical behaviour, dna binding and cleavage studies of substituted $\beta$-DiketimineCopper(II) and Zinc(II) complexes," International Journal of Innovative Research in Science, Engineering and Technology, vol. 04, no. 02, pp. 477-485, 2015.

[20] R. A. Steiner, D. Foreman, H. X. Lin et al., "Synthesis, characterization, crystal structures and biological activity of set of $\mathrm{Cu}$ (II) benzothiazole complexes: Artificial nucleases with cytotoxic activities," Journal of Inorganic Biochemistry, vol. 137, pp. 1-11, 2014.

[21] E. Kouris, S. Kalogiannis, F. Perdih, I. Turel, and G. Psomas, "Cobalt(II) complexes of sparfloxacin: Characterization, structure, antimicrobial activity and interaction with DNA and albumins," Journal of Inorganic Biochemistry, vol. 163, pp. 18-27, 2016.

[22] L.-Q. Chai, J.-J. Huang, H.-S. Zhang, Y.-L. Zhang, J.-Y. Zhang, and Y.-X. Li, "An unexpected cobalt(III) complex containing a Schiff base ligand: Synthesis, crystal structure, spectroscopic behavior, electrochemical property and SOD-like activity," Spectrochimica Acta Part A: Molecular and Biomolecular Spectroscopy, vol. 131, pp. 526-533, 2014.

[23] V. Thamilarasan, N. Sengottuvelan, A. Sudha, P. Srinivasan, and G. Chakkaravarthi, "Cobalt(III) complexes as potential anticancer agents: Physicochemical, structural, cytotoxic activity and DNA/protein interactions," Journal of Photochemistry and Photobiology B: Biology, vol. 162, pp. 558-569, 2016.

[24] L. Shivakumar, K. Shivaprasad, and H. D. Revanasiddappa, "Synthesis, spectroscopic characterization, antimicrobial, DNA binding and oxidative-induced DNA cleavage activities: New oxovanadium(IV) complexes of 2-(2-hydroxybenzylideneamino)isoindoline-1,3-dione," Spectrochimica Acta Part A: Molecular and Biomolecular Spectroscopy, vol. 97, pp. 659-666, 2012.

[25] A. R. O. Rodrigues, "Benzothienoquinolines: New one-pot synthesis and fluorescence studies of their interaction with DNA and polynucleotides," Journal of Photochemistry and Photobiology A: Chemistry, vol. 294, pp. 20-30, 2014.

[26] S. I. Liochev, "Reactive oxygen species and the free radical theory of aging," Free Radical Biology \& Medicine, vol. 60, pp. $1-4,2013$.

[27] G. Yan, Y. He, G. Li, Y. Xiong, P. Song, and R.-M. Wang, "Bovine Serum Albumin Metal Complexes for Mimic of SOD," Journal of Chemical Sciences, vol. 128, no. 11, pp. 1783-1788, 2016.

[28] B. Sarma, P. K. Bhattacharyya, and D. K. Das, "Synthesis, characterization and superoxide dismutase activity of bi-copper(II)bisacetato- $\mu$-phthalicacid[bis(benzyloxy)ethyl]ester," Journal of Chemical Sciences, vol. 127, no. 3, pp. 455-459, 2015. 
[29] Y. Nishida, I. Watanabe, and K. Unoura, "Model Compounds for Fe- or Mn-containing SOD and Their SOD-like Function," Chemistry Letters, vol. 20, no. 9, pp. 1517-1520, 1991.

[30] F. S. Archibald and I. Fridovich, "The scavenging of superoxide radical by manganous complexes: In vitro," Archives of Biochemistry and Biophysics, vol. 214, no. 2, pp. 452-463, 1982.

[31] E. Bienvenue, S. Choua, M.-A. Lobo-Recio et al., "Structure and superoxide dismutase activity of $\mathrm{Ru}(\mathrm{II}), \mathrm{Cu}(\mathrm{II})$, and $\mathrm{Mn}$ (II) macrocyclic complexes," Journal of Inorganic Biochemistry, vol. 57, no. 3, pp. 157-168, 1995.

[32] K. Djinovic, G. Pelosi, L. Antolini, and M. Bolognesi, “Threedimensional structure of superoxide dismutase: a crystallographic study on yeast sod and on the cobal,t substituted bovine erythrocyte enzyme at atomic resolution," Abstracts, vol. 182, 1987.

[33] J. R. Anacona and J. Diaz, "Synthesis, characterization and superoxide dismutase Actwity of the Manganese(II) mixed ligand complexes containing sulfathiazole," Journal of the Chilean Chemical Society, vol. 53, no. 4, pp. 1702-1704, 2008.

[34] A. Hospital, J. R. Goñi, M. Orozco, and J. L. Gelpí, "Molecular dynamics simulations: Advances and applications," Advances and Applications in Bioinformatics and Chemistry, vol. 8, no. 1 , pp. 37-47, 2015.

[35] S. Kumar, V. K. Basappa Chidananda, R. Hosakere Doddarevanna, V. Hamse Kameshwar, M. Kaur, and J. P. Jasinski, "2-((E)(6-fluorobenzo[d]thiazol-2-ylimino) methyl)-4-chlorophenol; synthesis, characterization, crystal structure, Hirshfeld surface analysis and BSA binding studies," Journal of Molecular Structure, vol. 1142, pp. 293-303, 2017.

[36] K. Zheng, F. Liu, Y.-T. Li, Z.-Y. Wu, and C.-W. Yan, "Synthesis and structure elucidation of new $\mu$-oxamido-bridged dicopper(II) complexes showing in vitro anticancer activity: Evaluation of DNA/protein-binding properties by experiment and molecular docking," Journal of Inorganic Biochemistry, vol. 156, pp. 75-88, 2016.

[37] L. S. Kumar, K. S. Prasad, and H. D. Revanasiddappa, "Synthesis, characterization, antioxidant, antimicrobial, DNA binding and cleavage studies of mononuclear $\mathrm{Cu}(\mathrm{II})$ and $\mathrm{Co}$ (II) complexes of 3-hydroxy-NI-(2-hydroxybenzylidene)-2naphthohydrazide," European Journal of Chemistry, vol. 2, no. 3, pp. 394-403, 2011.

[38] A. Wolfe, G. H. Shimer Jr., and T. Meehan, "Polycyclic aromatic hydrocarbons physically intercalate into duplex regions of denatured DNA," Biochemistry, vol. 26, no. 20, pp. 6392-6396, 1987.

[39] L. H. Abdel-Rahman, A. M. Abu-Dief, E. F. Newair, and S. K. Hamdan, "Some new nano-sized $\mathrm{Cr}(\mathrm{III}), \mathrm{Fe}(\mathrm{II}), \mathrm{Co}(\mathrm{II})$, and $\mathrm{Ni}(\mathrm{II})$ complexes incorporating 2-((E)-(pyridine-2-ylimino)methyl)napthalen-1-ol ligand: Structural characterization, electrochemical, antioxidant, antimicrobial, antiviral assessment and DNA interaction," Journal of Photochemistry and Photobiology B: Biology, vol. 160, pp. 18-31, 2016.

[40] H. Ohtsu, Y. Shimazaki, A. Odani et al., "Synthesis and characterization of imidazolate-bridged dinuclear complexes as active site models of Cu,Zn-SOD," Journal of the American Chemical Society, vol. 122, no. 24, pp. 5733-5741, 2000.

[41] A. Dileep Kumar, S. Naveen, H. K. Vivek, M. Prabhuswamy, N. K. Lokanath, and K. Ajay Kumar, "Synthesis, crystal and molecular structure of ethyl 2-(4-chlorobenzylidene)-3oxobutanoate: Studies on antioxidant, antimicrobial activities and molecular docking," Chemical Data Collections, vol. 5-6, pp. 36-45, 2016.
[42] K. R. Raghavendra, N. Renuka, V. H. Kameshwar, B. Srinivasan, K. Ajay Kumar, and S. Shashikanth, "Synthesis of lignan conjugates via cyclopropanation: Antimicrobial and antioxidant studies," Bioorganic \& Medicinal Chemistry Letters, vol. 26, no. 15, pp. 3621-3625, 2016.

[43] I. Wiegand, K. Hilpert, and R. E. W. Hancock, "Agar and broth dilution methods to determine the minimal inhibitory concentration (MIC) of antimicrobial substances," Nature Protocols, vol. 3, no. 2, pp. 163-175, 2008.

[44] F. A. Chavez, C. V. Nguyen, M. M. Olmstead, and P. K. Mascharak, "Synthesis, Properties, and Structure of a Stable Cobalt(III) Alkyl Peroxide Complex and Its Role in the Oxidation of Cyclohexane," Inorganic Chemistry, vol. 35, no. 21, pp. 6282-6291, 1996.

[45] L. Pogány, J. Moncol, M. Gál, I. Šalitroš, and R. Boča, "Four cobalt(III) Schiff base complexes - Structural, spectroscopic and electrochemical studies," Inorganica Chimica Acta, vol. 462, pp. 23-29, 2017.

[46] V. Gomathi and R. Selvameena, "Synthesis, characterization and biological activity of Schiff base complexes of sulfa drug with transition metals," Asian Journal of Chemistry, vol. 25, no. 4, pp. 2083-2086, 2013.

[47] D. P. Singh, K. Kumar, and C. Sharma, "New 14-membered octaazamacrocyclic complexes of divalent transition metal ions with their antimicrobial and spectral studies," Spectrochimica Acta Part A: Molecular and Biomolecular Spectroscopy, vol. 75, no. 1, pp. 98-105, 2010.

[48] A. B. P. Lever, Inorganic, Electronic spectroscopy, Elsevier, Elsevier, Amsterdam, Netherlands, 4th edition, 1984.

[49] M. S. Shongwe, S. K. M. Al-hatmi, H. M. Marques, and R. Smith, Spectroscopic models for cobalt(III)tyrosinate interactions, 2002.

[50] R. M. Patil and M. M. Prabhu, "Synthesis and characterisation of $\mathrm{Co}(\mathrm{II}, \mathrm{Ni}(\mathrm{II})$ and $\mathrm{Cu}(\mathrm{II})$ Complexes With Sodium Salt of pMethoxyisonitrosoacetophenone," vol. 8, pp. 52-58, 2010.

[51] S. Prema, A. Pasupathy, and S. R. Bheeter, "Synthesis and characterization of Nickel(II) and Copper(II) complexes of uramido benzoic acid," International journal of Scientific and Research Publications, vol. 6, pp. 721-723, 2016.

[52] K. I. Alexopoulou, E. Zagoraiou, T. F. Zafiropoulos et al., "Mononuclear anionic octahedral cobalt(III) complexes based on N-salicylidene-o-aminophenol and its derivatives: Synthetic, structural and spectroscopic studies," Spectrochimica Acta Part A: Molecular and Biomolecular Spectroscopy, vol. 136, pp. 122-130, 2015.

[53] N. G. Yernale and B. H. M. Mruthyunjayaswamy, "Synthesis, characterization, antimicrobial, dna cleavage, and in vitro cytotoxic studies of some metal complexes of schiff base ligand derived from thiazole and quinoline moiety," Bioinorganic Chemistry and Applications, vol. 2014, Article ID 314963, 17 pages, 2014.

[54] K. Suntharalingam, O. Mendoza, A. A. Duarte, D. J. Mann, and R. Vilar, "A platinum complex that binds non-covalently to DNA and induces cell death via a different mechanism than cisplatin," Metallomics, vol. 5, no. 5, pp. 514-523, 2013.

[55] A. Rambabu, M. Pradeep Kumar, S. Tejaswi, N. Vamsikrishna, and Shivaraj, "DNA interaction, antimicrobial studies of newly synthesized copper (II) complexes with 2-amino-6(trifluoromethoxy)benzothiazole Schiff base ligands," Journal of Photochemistry and Photobiology B: Biology, vol. 165, 2016.

[56] M. A. Hasan, N. Kumari, K. Singh, K. Singh, and L. Mishra, "Mixed ligand complexes of $\mathrm{Cu}(\mathrm{II}) / \mathrm{Zn}$ (II) ions containing 
$(\mathrm{m}-) /(\mathrm{p}-)$ carboxylato phenyl azo pentane 2,4-dione and 2,2/-bipyridine/1,10 phenanthroline: Synthesis, characterization, DNA binding, nuclease and topoisomerase I inhibitory activity," Spectrochimica Acta Part A: Molecular and Biomolecular Spectroscopy, vol. 152, Article ID 13978, pp. 208-217, 2016.

[57] A. Kathiravan and R. Renganathan, "Photoinduced interactions between colloidal $\mathrm{TiO}_{2}$ nanoparticles and calf thymus-DNA," Polyhedron, vol. 28, no. 7, pp. 1374-1378, 2009.

[58] R. Alizadeh, I. Yousuf, M. Afzal, S. Srivastav, S. Srikrishna, and F. Arjmand, "Enantiomeric fluoro-substituted benzothiazole Schiff base-valine $\mathrm{Cu}(\mathrm{II}) / \mathrm{Zn}(\mathrm{II})$ complexes as chemotherapeutic agents: DNA binding profile, cleavage activity, MTT assay and cell imaging studies," Journal of Photochemistry and Photobiology B: Biology, vol. 143, pp. 61-73, 2015.

[59] S. Baskaran, M. M. Krishnan, M. N. Arumugham, and R. Kumar, "DFT analysis and DNA binding, cleavage of copper(II) complexes," Journal of Molecular Liquids, vol. 221, pp. 1045-1053, 2016.

[60] K. G. Strothkamp and R. E. Strothkamp, "Fluorescence measurements of ethidium binding to DNA," Journal of Chemical Education, vol. 71, no. 1, pp. 77-79, 1994.

[61] R. Gup, O. Erer, and N. Dilek, "A rapid synthesis of 2substituted 1,2,3- triazole-1-oxide derivative starting from 4(methyl)isonitrosoacetophenone and its $\mathrm{Ni}(\mathrm{II})$ complex: Characterization, DNA binding and cleavage properties," Journal of Molecular Structure, vol. 1129, pp. 142-151, 2017.

[62] N. Shahabadi, S. Kashanian, and F. Darabi, "DNA binding and DNA cleavage studies of a water soluble cobalt(II) complex containing dinitrogen Schiff base ligand: The effect of metal on the mode of binding," European Journal of Medicinal Chemistry, vol. 45, no. 9, pp. 4239-4245, 2010.

[63] Y.-H. Zhou, W.-Q. Wan, D.-L. Sun, J. Tao, L. Zhang, and X.-W. Wei, "Synthesis, structure, and SOD-like activity of a copper(II) complex containing a bistriazole group," Zeitschrift für anorganische und allgemeine Chemie, vol. 640, no. 1, pp. 249253, 2014.

[64] Y. Anjaneyulu and R. P. Rao, "Preparation, characterization and antimicrobial activity studies on some ternary complexes of $\mathrm{Cu}$ (II) with acetylacetone and various salicylic acids," Synthesis and Reactivity in Inorganic, Metal-Organic, and Nano-Metal Chemistry, vol. 16, no. 2, pp. 257-272, 1986.

[65] L. Mishra and V. K. Singh, "Synthesis, structural and antifungal studies of $\mathrm{Co}$ (II, $\mathrm{Ni}$ (II, $\mathrm{Cu}(\mathrm{II})$ and $\mathrm{Zn}$ (II) complexes with new Schiff bases bearing benzimidazoles," Indian Journal of Chemistry, vol. 32, no. 5, pp. 446-457, 1993.

[66] L. Malhotra, S. Kumar, and K. S. Dhindsa, "Synthesis, characterization and microbiocidal activity of $\mathrm{Co}(\mathrm{II}), \mathrm{Ni}(\mathrm{II}), \mathrm{Cu}(\mathrm{II})$ and $\mathrm{Zn}$ (II) complexes of aryloxyacetic acid and hydrazide," Indian Journal of Chemistry, vol. 32A, pp. 457-459, 1993.

[67] R. V. Patel and S. W. Park, "Catalytic N-formylation for synthesis of 6-substituted-2-benzothiazolylimino-5-piperazinyl-4thiazolidinone antimicrobial agents," Research on Chemical Intermediates, vol. 41, no. 8, pp. 5599-5609, 2015.

[68] K. V. Dileep, V. Vijeesh, and C. Remya, "Rational design and interaction studies of combilexins towards duplex DNA," Molecular BioSystems, vol. 12, no. 3, pp. 860-867, 2016.

[69] N. Renuka, H. K. Vivek, G. Pavithra, and K. Ajay Kumar, "Synthesis of coumarin appended pyrazolyl-1,3,4-oxadiazoles and pyrazolyl-1,3,4-thiadiazoles: Evaluation of their in vitro antimicrobial and antioxidant activities and molecular docking studies," Russian Journal of Bioorganic Chemistry, vol. 43, no. 2, pp. 197-210, 2017. 

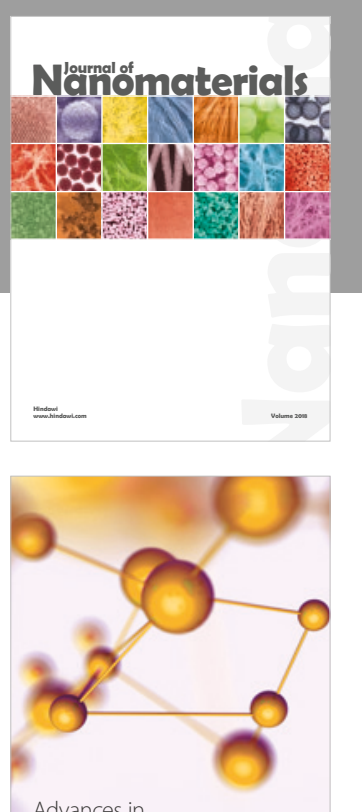

Physical Chemistry
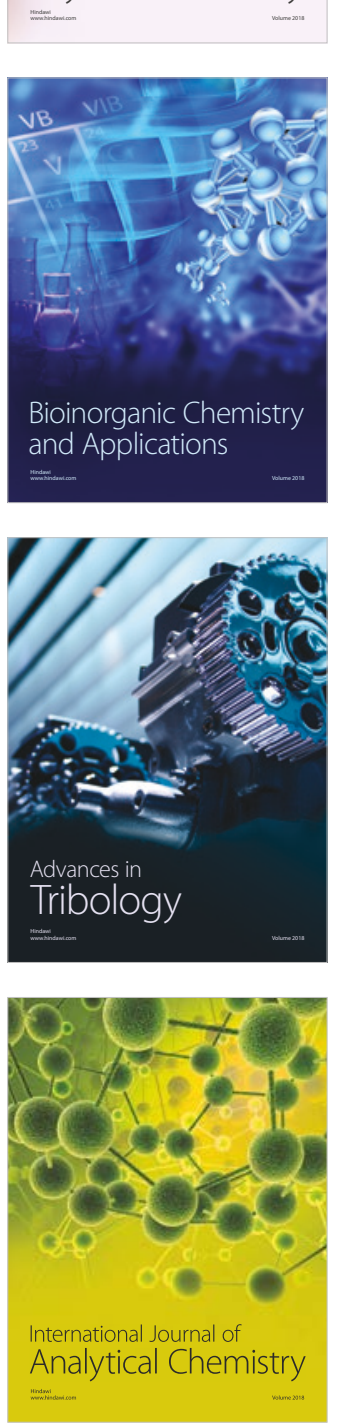

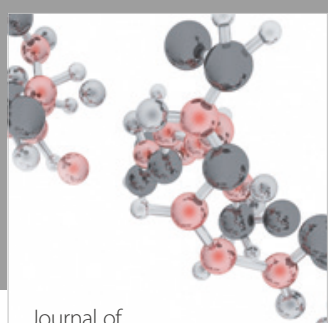

Analytical Methods

in Chemistry

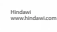

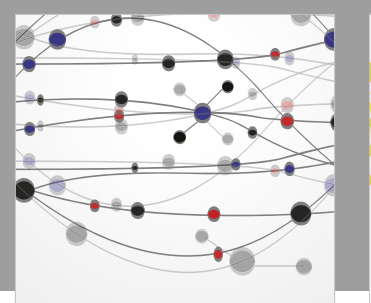

The Scientific World Journal

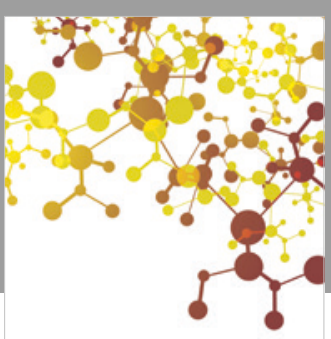

Journal of

Applied Chemistry
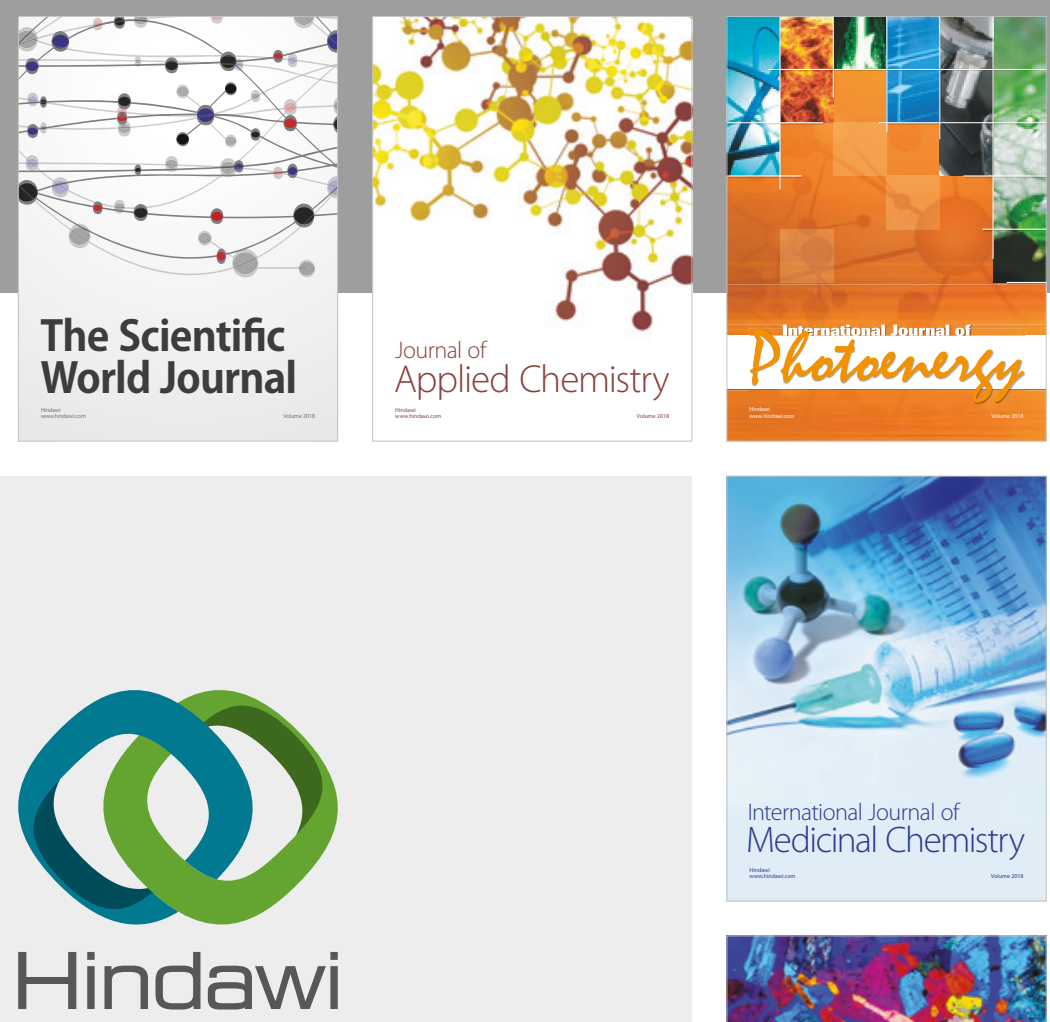

Submit your manuscripts at

www.hindawi.com
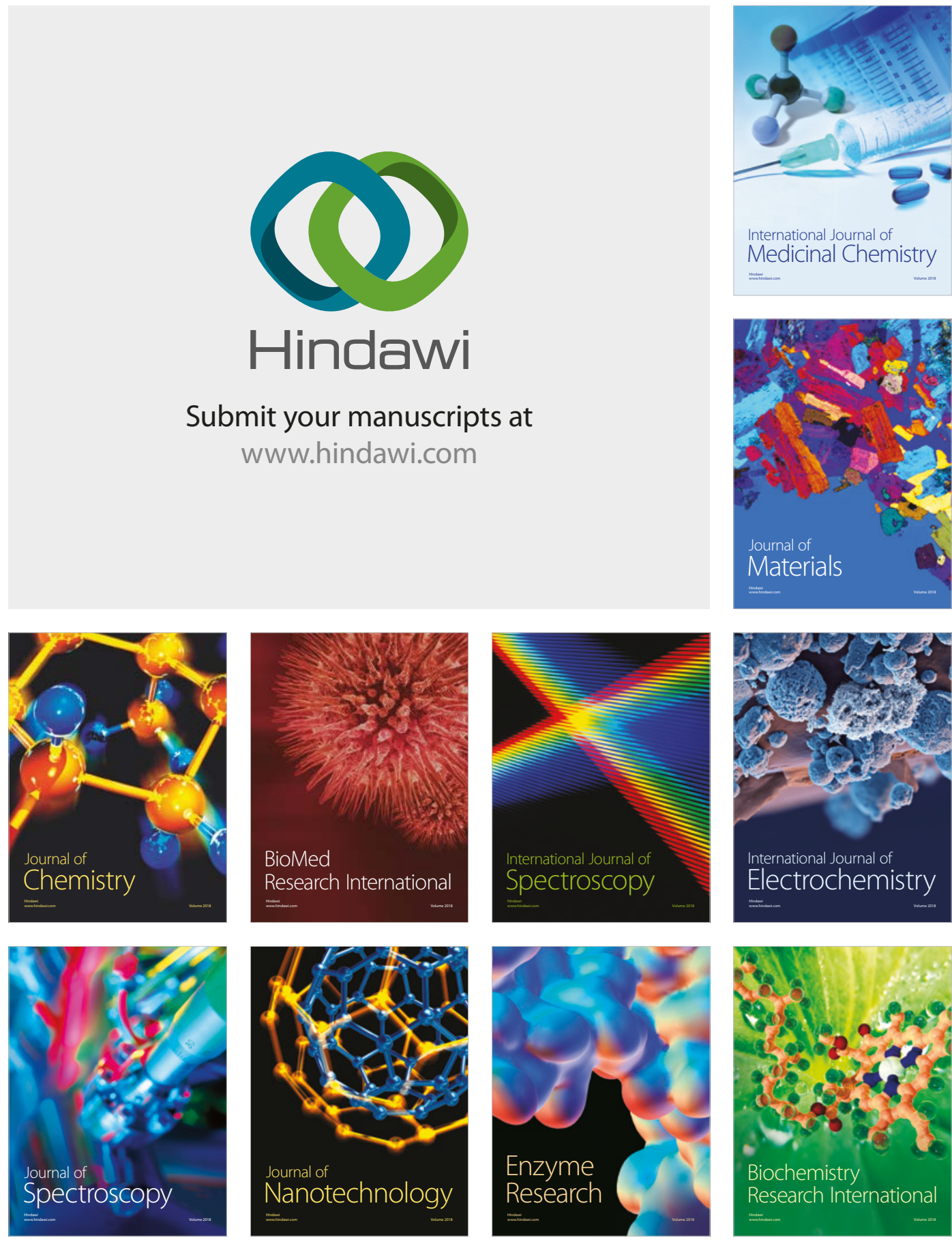
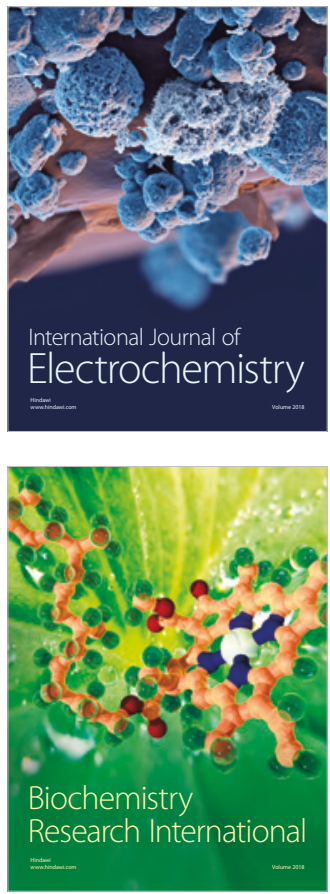